\title{
A series of 3D Porous Lanthanide-Substituted Polyoxometalate Frameworks Based on Rare Hexadecahedral $\left\{\mathrm{Ln}_{6} \mathrm{~W}_{8} \mathrm{O}_{28}\right\}$ Heterometallic Cage- shaped Clusters
}

Jin-Hua Liu, ${ }^{\dagger}$ Rong-Tao Zhang, ${ }^{\dagger}$ Jing-Zhang, ${ }^{\dagger}$ Dan Zhao,,${ }^{\ddagger}$ Xin-Xiong Li,${ }^{\dagger}$ Yan-Qiong Sun,${ }^{* \dagger}$ Shou-Tian Zheng ${ }^{* \dagger}$ $\dagger$ State Key Laboratory of Photocatalysis on Energy and Environment, College of Chemistry, Fuzhou University, Fuzhou, Fujian 350108, China.

\$ Fuqing Branch of Fujian Normal University, Fuqing, Fujian 350300, China..

This file includes:

$\begin{array}{ll}\text { Section 1: Experimental section } & \text { S1-S3 }\end{array}$

Section 2: Additional tables $\quad$ S3-S5

Section 3: Additional structural figures and characterizations $\quad$ S5-S17

$\begin{array}{lr}\text { Section 4: References } & \text { S18-S19 }\end{array}$ 


\section{Section 1: Experimental Section}

Materials and General methods: $\mathrm{Na}_{10}\left[\alpha-\mathrm{SiW}_{9} \mathrm{O}_{34}\right] \cdot 16 \mathrm{H}_{2} \mathrm{O}$ was synthesized on the basis of literature method and proved by IR spectroscopy. ${ }^{1}$ Other reactants and solvents were obtained from commercial sources and used for reactions without further purification. Powder X-ray diffraction (PXRD) analyses were recorded on a Rigaku Ultima IV diffractometer with $\mathrm{Cu} \mathrm{K} \alpha$ radiation $(\lambda=1.54178 \AA$ ). Thermogravimetric analysis (TGA) were performed on a Mettler Toledo TGA/SDTA 851e analyzer under an air-flow atmosphere with a heating rate of $10{ }^{\circ} \mathrm{C} / \mathrm{min}$ in the temperature of $30-800^{\circ} \mathrm{C}$. The infra-red (IR) spectra were recorded on a Nicolet iS50 at room temperature. Energydispersive spectrometry (EDS) analyses were performed using a Hirox SH-4000 M type desktop scanning electron microscope. UV-vis adsorption spectra were collected using a PerkinElmer Lambda 35 spectrophotometer to monitor the release process. Fluorescence spectra were measured on an Edinburgh Instrument FS980 TCSPC luminescence spectrometer by using crystalline samples. Variable-temperature susceptibility measurement was performed in the temperature range of $2-300 \mathrm{~K}$ at a magnetic field of $1 \mathrm{KOe}$ on crystalline samples with a Quantum Design PPMS-9T magnetometer. The experimental susceptibilities were corrected for the Pascal's constants.

Adsorption Analysis: Single-component gas measurements were performed with an Accelerated Surface Area and Porosimetry 2020 (ASAP 2020) surface area analyzer. All gases were used in the adsorption experiment of 99.999\% purity or higher.

Ionic conductivity experiments: Ac impedance measurements were carried out with a zennium/IM6 impedance analyzer over the frequency range from $0.1 \mathrm{~Hz}$ to $5 \mathrm{MHz}$ with an applied voltage of $50 \mathrm{mV}$. The relative humidity was controlled by a STIK Corp. CIHI-150B incubator. The sample was pressed to form a cylindrical pellet of crystalline powder sample $(\sim 1.0 \mathrm{~mm}$ thickness $\times 5 \mathrm{~mm} \phi)$ coated with C-pressed electrodes. Two silver electrodes were attached to both sides of pellet to form four end S3 terminals (quasi-four-probe method). The bulk conductivity was estimated by semicircle fittings of Nyquist plots.

Synthesis of $\mathrm{Na}_{2}\left[\mathbf{G d}_{2}\left(\mathrm{H}_{2} \mathbf{O}\right)_{11}\right]_{2}\left[\mathrm{Gd}_{3}\left(\mathrm{H}_{\mathbf{2}} \mathbf{O}\right)_{\mathbf{2}}\left(\boldsymbol{\alpha}-\mathrm{SiW}_{\mathbf{1 1}} \mathrm{O}_{\mathbf{3 9}}\right)_{2}\right]_{2} \cdot \mathbf{6 9 H}_{\mathbf{2}} \mathrm{O}(\mathbf{1 - G d}): \mathrm{Gd}\left(\mathrm{NO}_{3}\right)_{3} \cdot 6 \mathrm{H}_{2} \mathrm{O}(0.22 \mathrm{mmol}, 100$ $\mathrm{mg}), \mathrm{Na}_{10}\left[\alpha-\mathrm{SiW}_{9} \mathrm{O}_{34}\right] \cdot 16 \mathrm{H}_{2} \mathrm{O}(0.15 \mathrm{mmol}, 400 \mathrm{mg}), \mathrm{In}\left(\mathrm{NO}_{3}\right)_{3} \cdot 4.5 \mathrm{H}_{2} \mathrm{O}(0.26 \mathrm{mmol}, 100 \mathrm{mg})$, dodecanoic acid $(0.25$ $\mathrm{mmol}, 50 \mathrm{mg})$ and $\mathrm{NaClO}_{4}(0.70 \mathrm{mmol}, 100 \mathrm{mg})$ were dissolved in $4 \mathrm{~mL} \mathrm{H}_{2} \mathrm{O}$ in a $20 \mathrm{~mL}$ vial, and then the mixture was heated to $100{ }^{\circ} \mathrm{C}$ for 4 days and cooled to room temperature. The $\mathrm{pH}$ values before and after the reaction were 4.3 and 2.5 respectively. White prism crystals of 1-Gd suitable for X-ray diffraction experiments were obtained by filtration, washed with $\mathrm{H}_{2} \mathrm{O}$ and air-dried. Yield: about $52.6 \%$ (based on $\left.\mathrm{Gd}\left(\mathrm{NO}_{3}\right)_{3} \cdot 6 \mathrm{H}_{2} \mathrm{O}\right)$. IR $\left(\mathrm{KBr}\right.$ pellet, $\left.v / \mathrm{cm}^{-1}\right)$ : 3254(vs), 1599(s), 1432(w), 1306(w), 1260(w), 993(w), 948(m), 832(m), 625(w).

Synthesis of $\mathrm{Na}_{2}\left[\mathrm{Eu}_{2}\left(\mathrm{H}_{2} \mathrm{O}\right)_{11}\right]_{2}\left[\mathrm{Eu}_{3}\left(\mathrm{H}_{2} \mathrm{O}\right)_{2}\left(\alpha-\mathrm{SiW}_{11} \mathrm{O}_{39}\right)_{2}\right]_{2} \cdot \mathbf{6 9 H}_{2} \mathrm{O}(1-\mathrm{Eu})$ : The reaction process of 1-Eu is similar 
to 1-Gd except that $\mathrm{Eu}\left(\mathrm{NO}_{3}\right)_{3} \cdot 6 \mathrm{H}_{2} \mathrm{O}(0.22 \mathrm{mmol}, 100 \mathrm{mg})$ was used to replace $\mathrm{Gd}\left(\mathrm{NO}_{3}\right)_{3} \cdot 6 \mathrm{H}_{2} \mathrm{O}(0.22 \mathrm{mmol}, 100$ mg). Yield: $48.3 \%$ (based on $\mathrm{Eu}\left(\mathrm{NO}_{3}\right)_{3} \cdot 6 \mathrm{H}_{2} \mathrm{O}$ ). IR: 3248(vs), 1623(vs), 993(w), 948(w), 826(w), 619(w).

Synthesis of $\mathrm{Na}_{2}\left[\mathrm{~Tb}_{2}\left(\mathrm{H}_{2} \mathrm{O}\right)_{11}\right]_{2}\left[\mathrm{~Tb}_{3}\left(\mathrm{H}_{2} \mathrm{O}\right)_{2}\left(\alpha-\mathrm{SiW}_{11} \mathrm{O}_{39}\right)_{2}\right]_{2} \cdot 69 \mathrm{H}_{2} \mathrm{O}(1-\mathrm{Tb})$ : The reaction process of 1-Tb is similar to 1-Gd except that $\mathrm{Tb}\left(\mathrm{NO}_{3}\right)_{3} \cdot 6 \mathrm{H}_{2} \mathrm{O}(0.55 \mathrm{mmol}, 250 \mathrm{mg})$ was used to replace $\mathrm{Gd}\left(\mathrm{NO}_{3}\right)_{3} \cdot 6 \mathrm{H}_{2} \mathrm{O}(0.22 \mathrm{mmol}, 100$ mg). Yield: 50.4\% (based on $\left.\mathrm{Tb}\left(\mathrm{NO}_{3}\right)_{3} \cdot 6 \mathrm{H}_{2} \mathrm{O}\right)$. IR: 3243(vs), 1618(vs), 1416(w), 1008(w), 948(m), 832(w), 614(w). Synthesis of $\mathrm{Na}_{2}\left[\mathrm{Dy}_{2}\left(\mathrm{H}_{2} \mathrm{O}\right)_{11}\right]_{2}\left[\mathrm{Dy}_{3}\left(\mathrm{H}_{2} \mathrm{O}\right)_{2}\left(\alpha-\mathrm{SiW}_{11} \mathrm{O}_{39}\right)_{2}\right]_{2} \cdot 69 \mathrm{H}_{2} \mathrm{O}$ (1-Dy): The reaction process of 1-Dy is similar to 1-Gd except that $\mathrm{Dy}\left(\mathrm{NO}_{3}\right)_{3} \cdot 6 \mathrm{H}_{2} \mathrm{O}(0.65 \mathrm{mmol}, 300 \mathrm{mg})$ was used to replace $\mathrm{Gd}\left(\mathrm{NO}_{3}\right)_{3} \cdot 6 \mathrm{H}_{2} \mathrm{O}(0.22 \mathrm{mmol}, 100$ mg). Yield: $58.5 \%$ (based on Dy $\left.\left(\mathrm{NO}_{3}\right)_{3} \cdot 6 \mathrm{H}_{2} \mathrm{O}\right)$. IR: 3239(vs), 1618(vs),1397(w), 993(w), 924(w), 836(w), 700(w), 619(w).

Synthesis of $\mathrm{Na}_{2}\left[\mathrm{Sm}_{2}\left(\mathrm{H}_{2} \mathrm{O}\right)_{11}\right]_{2}\left[\mathrm{Sm}_{3}\left(\mathrm{H}_{2} \mathrm{O}\right)_{2}\left(\alpha-\mathrm{SiW}_{11} \mathrm{O}_{39}\right)_{2}\right]_{2} \cdot 69 \mathrm{H}_{2} \mathrm{O}(1-\mathrm{Sm})$ : The reaction process of 1-Sm is similar to 1-Gd except that $\mathrm{Sm}\left(\mathrm{NO}_{3}\right)_{3} \cdot 6 \mathrm{H}_{2} \mathrm{O}(0.45 \mathrm{mmol}, 200 \mathrm{mg})$ was used to replace $\mathrm{Gd}\left(\mathrm{NO}_{3}\right)_{3} \cdot 6 \mathrm{H}_{2} \mathrm{O}(0.22 \mathrm{mmol}$, $100 \mathrm{mg}$ ). Yield: $38.6 \%$ (based on $\left.\mathrm{Sm}\left(\mathrm{NO}_{3}\right)_{3} \cdot 6 \mathrm{H}_{2} \mathrm{O}\right)$. IR: 3233(vs), 1614(vs), 1427(w), 1255(w), 1144(w), 998(w), 924(m), 836(m), 640(w).

Synthesis discussion: The compounds 1- $\mathbf{L n}(\mathrm{Ln}=\mathrm{Sm}, \mathrm{Eu}, \mathrm{Gd}, \mathrm{Tb}$ and $\mathrm{Dy})$ were obtained from the reaction of $\mathrm{Ln}\left(\mathrm{NO}_{3}\right)_{3} \cdot 6 \mathrm{H}_{2} \mathrm{O}(\mathrm{Ln}=\mathrm{Sm}, \mathrm{Eu}, \mathrm{Gd}, \mathrm{Tb}$ and $\mathrm{Dy}), \mathrm{Na}_{10}\left[\alpha-\mathrm{SiW}_{9} \mathrm{O}_{34}\right] \cdot 16 \mathrm{H}_{2} \mathrm{O}, \mathrm{In}\left(\mathrm{NO}_{3}\right)_{3} \cdot 4.5 \mathrm{H}_{2} \mathrm{O}$ and dodecanoic acid. We have tried to synthesize isostructural 1- $\mathbf{L n}\left(\mathrm{Ln}=\mathrm{Y}^{3+}, \mathrm{La}^{3+}, \mathrm{Yb}^{3+}, \mathrm{Er}^{3+}\right)$ using light lanthanide $\mathrm{Y}^{3+}, \mathrm{La}^{3+}$ salts and heavy lanthanide $\mathrm{Yb}^{3+}, \mathrm{Er}^{3+}$ salts, but no analogous products were obtained. The acid environment $(\mathrm{pH}=2.5)$ provided by organic dodecanoic acid is one of the important factors for the syntheses of 1-Ln. During the preparation of 1-Gd, the $\mathrm{pH}$ value of the reaction solution is 3.5 without the presence of dodecanoic acid. But the $\mathrm{pH}$ can be lowered to 2.5 after the addition of tiny amounts of dodecanoic acid. So dodecanoic acid might serve as a special pH adjustor. At the same time, we tried to replace dodecanoic acid with other organic acid such as pyridin-4-bronic acid, toluene-4-sulfonic acid, and 1,3,5-benzenetricarboxylic acid as $\mathrm{pH}$ adjustor under the same conditions, unfortunately a large amount of unknown white powder were generated. The $\mathrm{In}\left(\mathrm{NO}_{3}\right)_{3} \cdot 4.5 \mathrm{H}_{2} \mathrm{O}$ also plays an important role in the formation 1-Gd, though it is not found in the final product. Such metal salt may act as a mineralizer during the reaction. So we come to the conclusion that the dodecanoic acid and $\operatorname{In}\left(\mathrm{NO}_{3}\right)_{3} \cdot 4.5 \mathrm{H}_{2} \mathrm{O}$ are necessary for the self-assembly of 1-Ln

Single-crystal structure analysis: Single-crystal X-ray diffraction data of 1-Gd were collected on Bruker Apex Duo CCD diffractometer with a graphite-monochromatized Mo K $\alpha$ radiation $(\lambda=0.71073 \AA)$ operating at $298 \mathrm{~K}$. The structure of 1-Gd was solved through direct methods and refined by full-matrix least-squares refinements based on $F^{2}$ adopting the SHELX-2014 program package. ${ }^{2}$ The disordered solvent molecules in 1-Gd were removed by 
the SQUEEZE program in PLATON. ${ }^{3}$ All non-H atoms were located with successive difference Fourier syntheses and refined anisotropically. The $\mathrm{H}$ atoms of the free water molecules and coordinated water molecule have not been included in the final refinement. Crystallographic data and structure refinements for 1-Gd are summarized in Table S1. CCDC 1938608 contains supplementary crystallographic data for this paper. These data can be obtained free of charge from The Cambridge Crystallographic Data Centre via www.ccdc.cam.ac.uk/data_request/cif.

\section{Section 2: Additional table}

Table S1 Crystal Data and Structure Refinement for 1-Gd.

\begin{tabular}{|c|c|}
\hline & 1-Gd \\
\hline Empirical formula & $\mathrm{Gd}_{10} \mathrm{Na}_{2} \mathrm{O}_{263} \mathrm{Si}_{4} \mathrm{~W}_{44} \mathrm{H}_{69}$ \\
\hline Formula weight & 14097.17 \\
\hline Crystal system & Monoclinic \\
\hline Space group & $P 2_{1} / n$ \\
\hline$a(\AA)$ & $13.7404(18)$ \\
\hline$b(\AA)$ & $26.426(3)$ \\
\hline$c(\AA)$ & $29.898(4)$ \\
\hline$\alpha\left(^{\circ}\right)$ & 90 \\
\hline$\beta\left(^{\circ}\right)$ & $93.635(2)$ \\
\hline$\gamma\left({ }^{\circ}\right)$ & 90 \\
\hline$V\left(\AA^{3}\right)$ & $10834(2)$ \\
\hline$Z$ & 2 \\
\hline$F(000)$ & 11052 \\
\hline Crystal size $/ \mathrm{mm}^{3}$ & $0.22 \times 0.19 \times 0.14$ \\
\hline$\theta$ range $/{ }^{\circ}$ & 1.541 to 25.127 \\
\hline \multirow[t]{3}{*}{ Limiting indices } & $-16<=\mathrm{h}<=16$ \\
\hline & $-31<=\mathrm{k}<=31$ \\
\hline & $-32<=1<=35$ \\
\hline$\rho_{\text {calcd }}\left(\mathrm{g} \mathrm{cm}^{-3}\right)$ & 3.962 \\
\hline Temperature (K) & $298(2)$ \\
\hline$\mu\left(m m^{-1}\right)$ & 26.383 \\
\hline Refl. Collected & 72640 \\
\hline Independent relf. & 19226 \\
\hline Parameters & 1154 \\
\hline
\end{tabular}




\begin{tabular}{ll}
\hline$R_{\text {int }}$ & 0.0737 \\
GOF on $\mathrm{F}^{2}$ & 1.041 \\
Final $R$ indices $(I=2 \sigma(I))$ & $R_{I}=0.0865, w R_{2}=0.1978$ \\
$R$ indices (all data) & $R_{I}=0.1277, w R_{2}=0.2291$ \\
\hline
\end{tabular}

$\mathrm{R}_{1}=\sum|| \mathrm{F}_{\mathrm{o}}|-| \mathrm{F}_{\mathrm{c}}\left|/ \sum\right| \mathrm{F}_{\mathrm{o}} \mid \cdot \mathrm{wR}_{2}=\left[\sum \mathrm{w}\left(\mathrm{F}_{\mathrm{o}}^{2}-\mathrm{F}_{\mathrm{c}}^{2}\right)^{2} / \sum \mathrm{w}\left(\mathrm{F}_{\mathrm{o}}{ }^{2}\right)^{2}\right]^{1 / 2} ; \mathrm{w}=1 /\left[\sigma^{2}\left(\mathrm{~F}_{\mathrm{o}}{ }^{2}\right)+(\mathrm{xP})^{2}+\mathrm{yP}\right], \mathrm{P}=\left(\mathrm{F}_{\mathrm{o}}^{2}+2 \mathrm{~F}_{\mathrm{c}}^{2}\right) / 3$, where $\mathrm{x}=0.132300$, $\mathrm{y}=0$ for $\mathbf{1 - G d}$.

Table S2 Unit cell parameters of 1-Eu, 1-Tb, 1-Dy and 1-Sm with isomorphic structures of 1-Gd.

\begin{tabular}{|c|l|}
\hline 1-Gd & $a=13.7404(18) \AA, b=26.426(3) \AA, c=29.898(4) \AA, \alpha=90^{\circ}, \beta=93.6^{\circ}, \gamma=90^{\circ}, V=10834(2) \AA^{3}$ \\
\hline 1-Sm & $a=14.69 \AA, b=26.10 \AA, c=29.67 \AA, \alpha=90^{\circ}, \beta=95.60^{\circ}, \gamma=90^{\circ}, V=11324 \AA^{3}$ \\
\hline 1-Eu & $a=14.70 \AA, b=26.21 \AA, c=29.92 \AA, \alpha=90^{\circ}, \beta=95.49^{\circ}, \gamma=90^{\circ}, V=11476 \AA^{3}$ \\
\hline 1-Tb & $a=13.90 \AA, b=26.51 \AA, c=30.01 \AA, \alpha=90^{\circ}, \beta=93.83^{\circ}, \gamma=90^{\circ}, V=11034 \AA^{3}$ \\
\hline 1-Dy & $a=14.54 \AA, b=26.28 \AA, c=30.05 \AA, \alpha=90^{\circ}, \beta=95.12^{\circ}, \gamma=90^{\circ}, V=11434 \AA^{3}$ \\
\hline
\end{tabular}

Table S3 Comparison of the conductivity of 1-Gd with those of some representative heteropolyoxometalates conducting materials.

\begin{tabular}{|c|c|c|c|}
\hline Compounds & $\begin{array}{l}\text { Conductivit } \\
\mathrm{y}\left(\mathrm{S} \mathrm{cm}^{-1}\right)\end{array}$ & $\begin{array}{l}\text { Condition } \\
\text { (Temp., RH) }\end{array}$ & Reference \\
\hline 1-Gd & $3.54 \times 10^{-3}$ & $85^{\circ} \mathrm{C}, 98 \% \mathrm{RH}$ & This work \\
\hline$\left\{\left[\mathrm{W}_{14} \mathrm{Ce}^{\mathrm{IV}}{ }_{6} \mathrm{O}_{61}\right]\left(\left[\mathrm{W}_{3} \mathrm{Bi}_{6} \mathrm{Ce}^{\mathrm{III}}{ }_{3}\left(\mathrm{H}_{2} \mathrm{O}\right)_{3} \mathrm{O}_{14}\right]\left[\mathrm{B}-\alpha-\mathrm{BiW}_{9} \mathrm{O}_{33}\right]_{3}\right)_{2}\right\}^{34-}$ & $2.4 \times 10^{-3}$ & $25^{\circ} \mathrm{C}, 90 \% \mathrm{RH}$ & S4 \\
\hline$\left[\mathrm{Cu}_{3}\left(\mu_{3}-\mathrm{OH}\right)\left(\mathrm{H}_{2} \mathrm{O}\right)_{3}(\mathrm{atz})_{3}\right]_{3}\left[\mathrm{P}_{2} \mathrm{~W}_{18} \mathrm{O}_{62}\right] \cdot 14 \mathrm{H}_{2} \mathrm{O}$ & $4.4 \times 10^{-6}$ & $25^{\circ} \mathrm{C}, 97 \% \mathrm{RH}$ & S5 \\
\hline $\begin{array}{l}{[\mathrm{Co}(\mathrm{bpz})(\mathrm{Hbpz})]\left[\mathrm{Co}\left(\mathrm{SO}_{4}\right)_{0.5}\left(\mathrm{H}_{2} \mathrm{O}\right)_{2}(\mathrm{bpz})\right]_{4}\left[\mathrm{PMo}_{8} \mathrm{VI}_{8} \mathrm{Mo}_{4} \mathrm{~V}^{\mathrm{IV}_{4}}\right.} \\
\left.\mathrm{O}_{42}\right] \cdot 13 \mathrm{H}_{2} \mathrm{O}\end{array}$ & $1.5 \times 10^{-3}$ & $75^{\circ} \mathrm{C}, 98 \% \mathrm{RH}$ & S6 \\
\hline $\begin{array}{l}{\left[\mathrm{Ce}^{\mathrm{III}}\left(\mathrm{H}_{2} \mathrm{O}\right)_{6}\right]\left\{\left[\mathrm{Ce}^{\mathrm{IV}}{ }_{7} \mathrm{Ce}^{\mathrm{III}}{ }_{3} \mathrm{O}_{6}(\mathrm{OH})_{6}\left(\mathrm{CO}_{3}\right)\left(\mathrm{H}_{2} \mathrm{O}\right)_{11}\right]\left[\left(\mathrm{P}_{2} \mathrm{~W}_{16} \mathrm{O}_{59}\right)\right]\right.} \\
3\} 16\end{array}$ & $2.65 \times 10^{-4}$ & $100{ }^{\circ} \mathrm{C}, 75 \% \mathrm{RH}$ & $\mathrm{S} 7$ \\
\hline $\mathrm{Cu}_{6}(\mathrm{Trz})_{10}\left(\mathrm{H}_{2} \mathrm{O}\right)_{4}\left[\mathrm{H}_{2} \mathrm{SiW}_{12} \mathrm{O}_{40}\right] \cdot 8 \mathrm{H}_{2} \mathrm{O}$ & $1.84 \times 10^{-6}$ & $95^{\circ} \mathrm{C}, 95 \% \mathrm{RH}$ & S8 \\
\hline$\left[\mathrm{H}_{3}(3-\mathrm{PyBim})_{2}\right]\left[\mathrm{PMo}_{12} \mathrm{O}_{40}\right] \cdot 3.5 \mathrm{H}_{2} \mathrm{O} \cdot \mathrm{CH}_{3} \mathrm{CN} \cdot \mathrm{CH}_{3} \mathrm{OH}$ & $3.34 \times 10^{-3}$ & $100{ }^{\circ} \mathrm{C}, 95 \% \mathrm{RH}$ & S9 \\
\hline$\left[\mathrm{H}_{3}(3-\mathrm{PyBim})_{2}\right]\left[\mathrm{PMo}_{12} \mathrm{O}_{40}\right] \cdot 4 \mathrm{H}_{2} \mathrm{O} \cdot \mathrm{CH}_{3} \mathrm{CN}$ & $1.36 \times 10^{-3}$ & $100{ }^{\circ} \mathrm{C}, 95 \% \mathrm{RH}$ & $\mathrm{S} 10$ \\
\hline$\left\{\mathrm{H}\left[\mathrm{Ni}(\mathrm{Hbpdc})\left(\mathrm{H}_{2} \mathrm{O}\right)_{2}\right]_{2}\left[\mathrm{PW}_{12} \mathrm{O}_{40}\right] \cdot 8 \mathrm{H}_{2} \mathrm{O}\right\}_{\mathrm{n}}$ & $1.35 \times 10^{-3}$ & $100{ }^{\circ} \mathrm{C}, 95 \% \mathrm{RH}$ & $\mathrm{S} 11$ \\
\hline $\begin{array}{l}{\left[\mathrm{M}\left(\mathrm{H}_{2} \mathrm{O}\right)_{8}\right]\left[\mathrm{H}\left(\mathrm{H}_{2} \mathrm{O}\right)_{2.3}\right](\mathrm{HINO})_{4}\left[\mathrm{PXO}_{40}\right] \quad(\mathrm{M}=\mathrm{Zn}, \quad \mathrm{Mn}, \mathrm{Cu}} \\
\mathrm{X}=\mathrm{W}, \mathrm{Mo})\end{array}$ & $1.30 \times 10^{-3}$ & $100{ }^{\circ} \mathrm{C}, 95 \% \mathrm{RH}$ & $\mathrm{S} 12$ \\
\hline
\end{tabular}

Hatz = 3-amino-1, 2, 4-triazolate; $\mathrm{H}_{2} \mathrm{bpz}=3$, 3', 5, 5'-tetramethyl-4, 4'-bipyrazole; Trz =1, 2, 4-triazole; 3-PyBim = 2-(3-pyridyl) benzimidazole; $\mathrm{H}_{2}$ bpdc $=2$, 2'-bipyridyl-3,3'-dicarboxylic acid; $\mathrm{HINO}=N$-oxide 


\section{Section 3: Additional structural figures and characterizations}

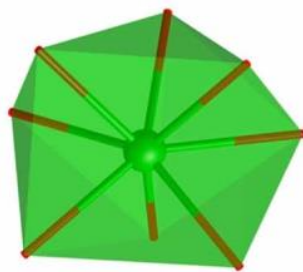

Gd1

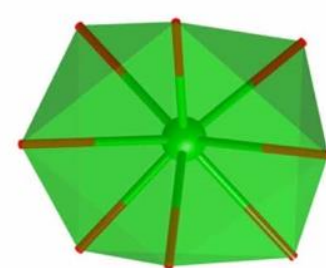

Gd2

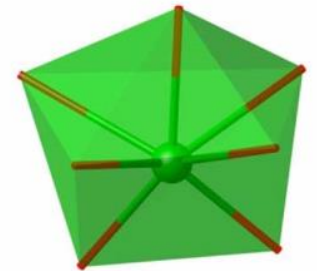

Gd3

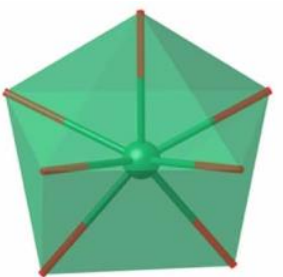

Gd4

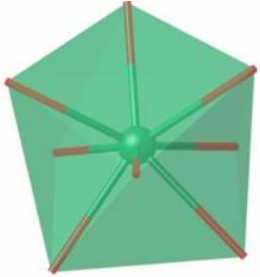

Gd5

Figure S1 View of the coordination environments of $\mathrm{Gd}^{3+}$ ions in 1-Gd.

a)

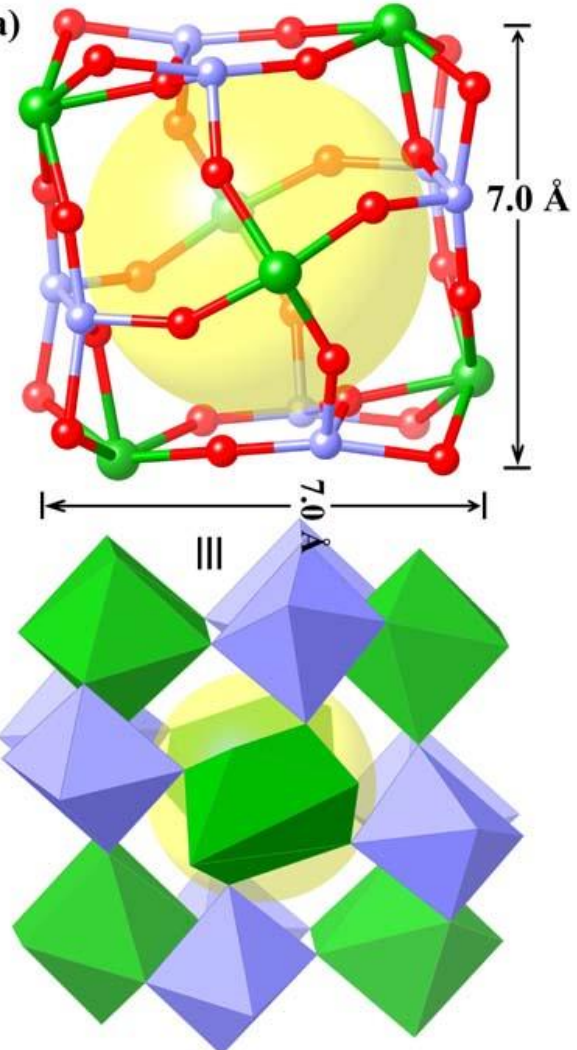

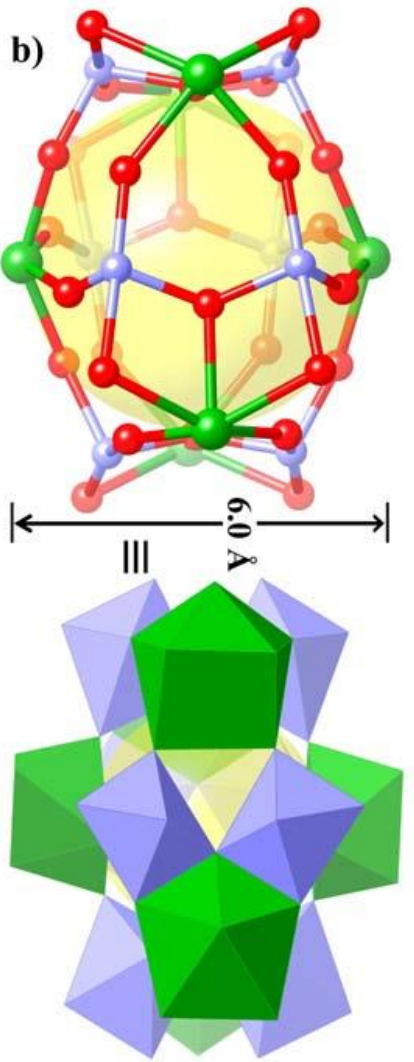

Figure S2 Hexadecahedral cage-shaped heterometallic cluster $\left\{\mathrm{Gd}_{6} \mathrm{~W}_{8} \mathrm{O}_{28}\right\}$ with a dimension of $7.0 \times 7.0 \times 6.0 \AA^{3}$. 


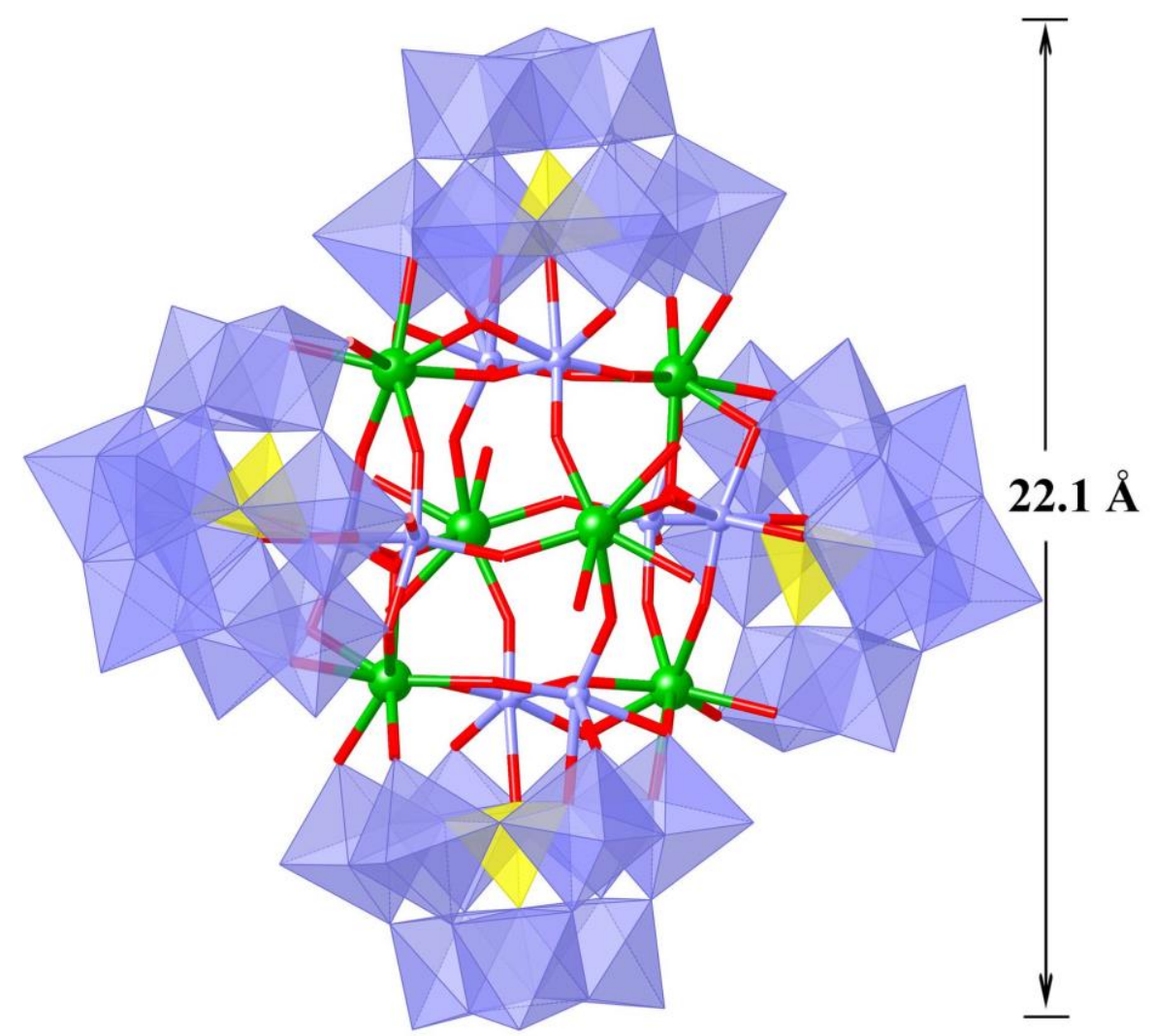

Figure $\mathbf{S 3}$ View of a size of $\left\{\left[\mathrm{Ln}_{3}\left(\mathrm{H}_{2} \mathrm{O}\right)_{3}\left(\alpha-\mathrm{SiW}_{11} \mathrm{O}_{39}\right)_{2}\right]_{2}\right\}^{14-}$ polyanion along the $a$ direction.

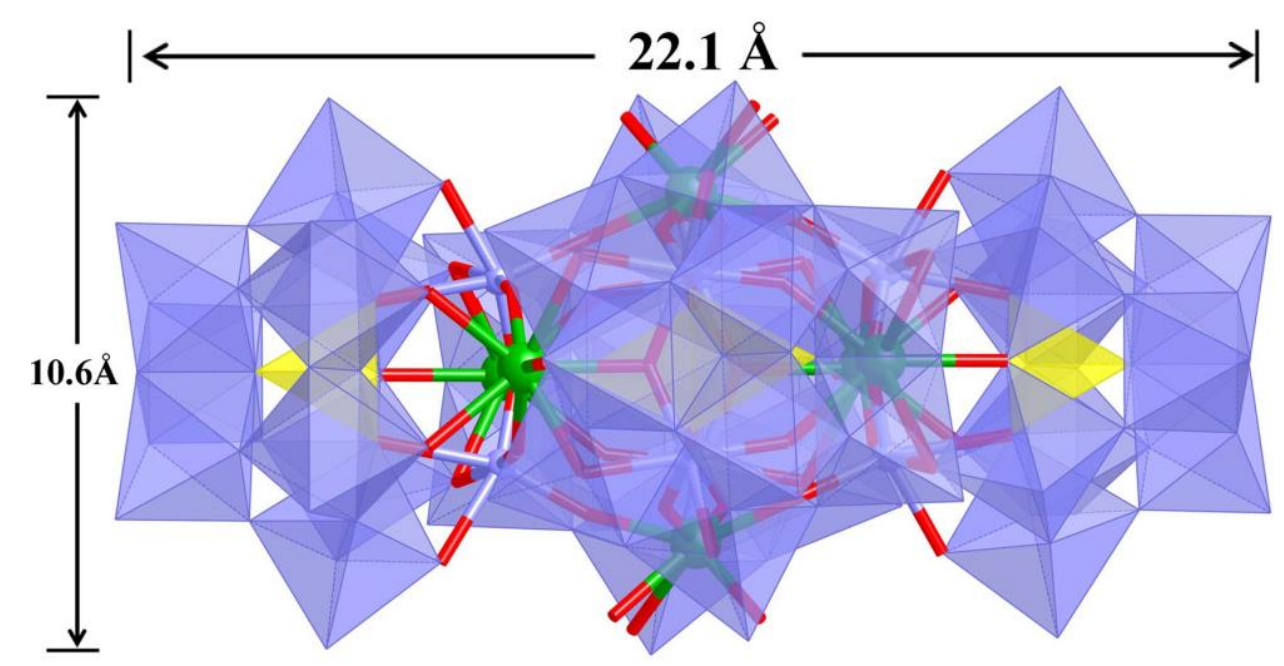

Figure $\mathbf{S} 4$ View of a size of $\left\{\left[\mathrm{Ln}_{3}\left(\mathrm{H}_{2} \mathrm{O}\right)_{3}\left(\alpha-\mathrm{SiW}_{11} \mathrm{O}_{39}\right)_{2}\right]_{2}\right\}^{14-}$ polyanion along the $c$ direction. 

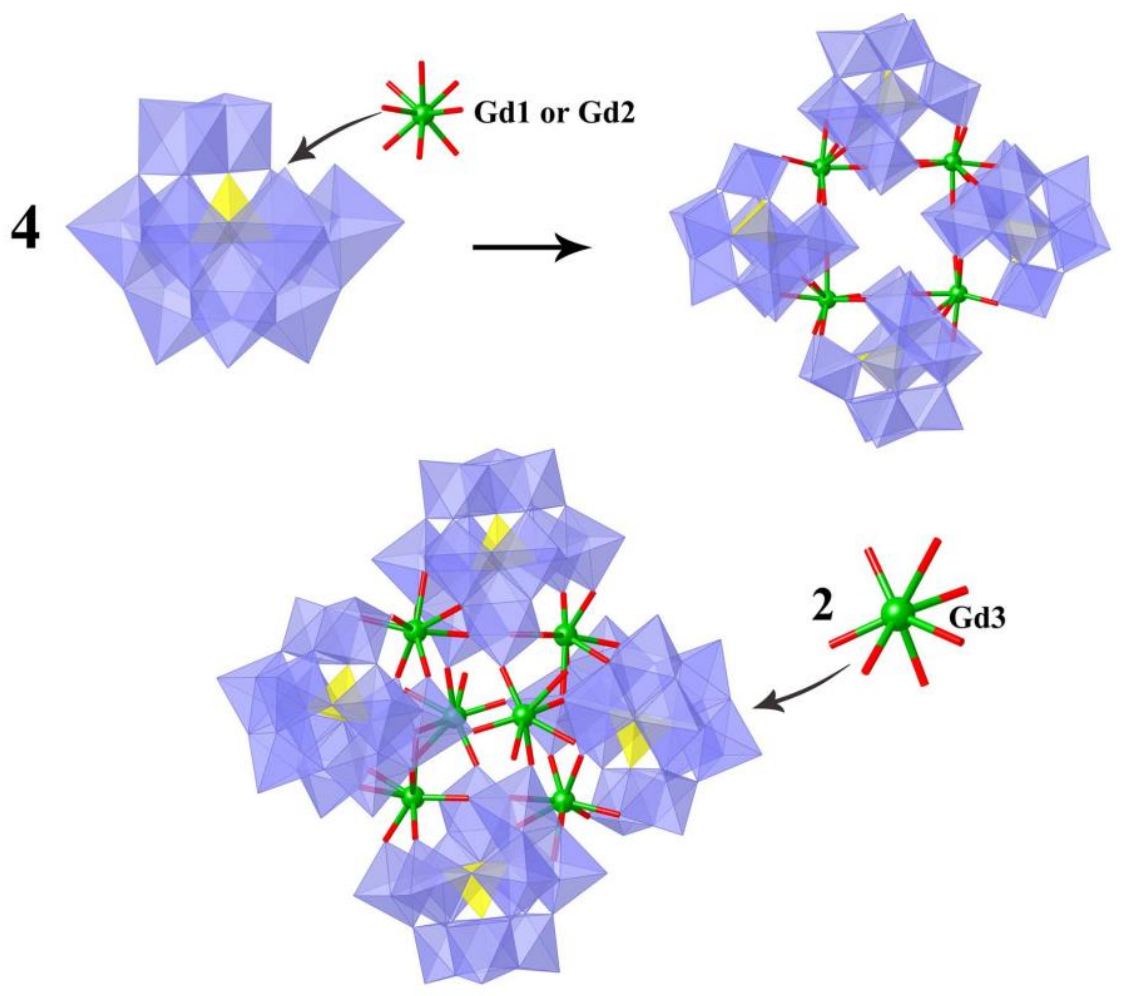

Figure S5 The assembly of tetrameric $\left\{\left[\mathrm{Ln}_{3}\left(\mathrm{H}_{2} \mathrm{O}\right)_{3}\left(\alpha-\mathrm{SiW}_{11} \mathrm{O}_{39}\right)_{2}\right]_{2}\right\}^{14-}$ cluster.

a)

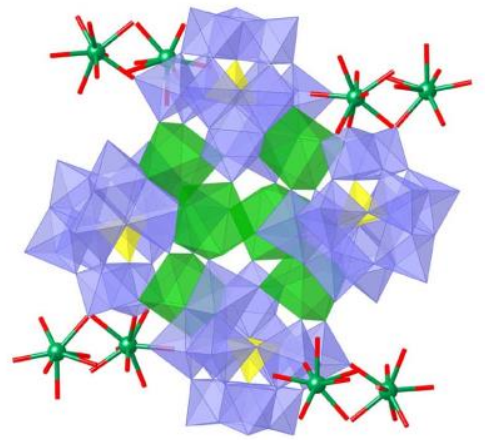

d)

A

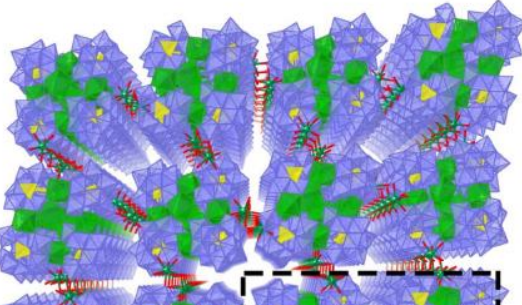

A

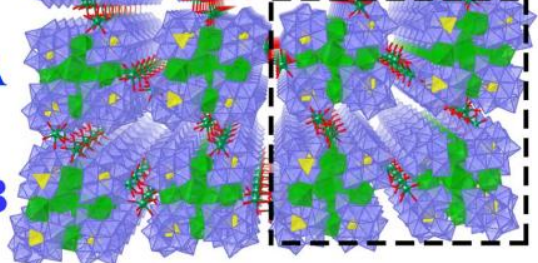

b)

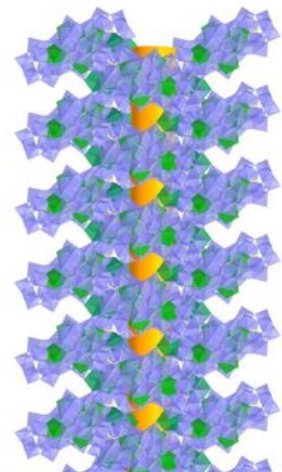

c)
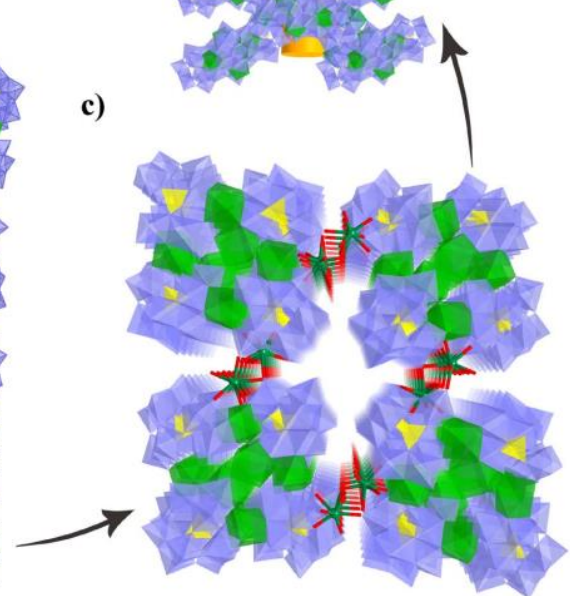

Figure S6 (a) View of $\left\{\left[\mathrm{Ln}_{3}\left(\mathrm{H}_{2} \mathrm{O}\right)_{3}\left(\alpha-\mathrm{SiW}_{11} \mathrm{O}_{39}\right)_{2}\right]_{2}\right\}^{14-}$ cluster linked by eight $\mathrm{Gd}^{3+}$ ions. (b and c) View of the onedimensional " $\mathrm{H}$ "-shaped channel running along $a$ axis. (d) View of the 3D structure via alternately connection of the centrosymmetric $2 \mathrm{D}$ layers in $\cdots \mathrm{ABAB} \cdots$ mode. 


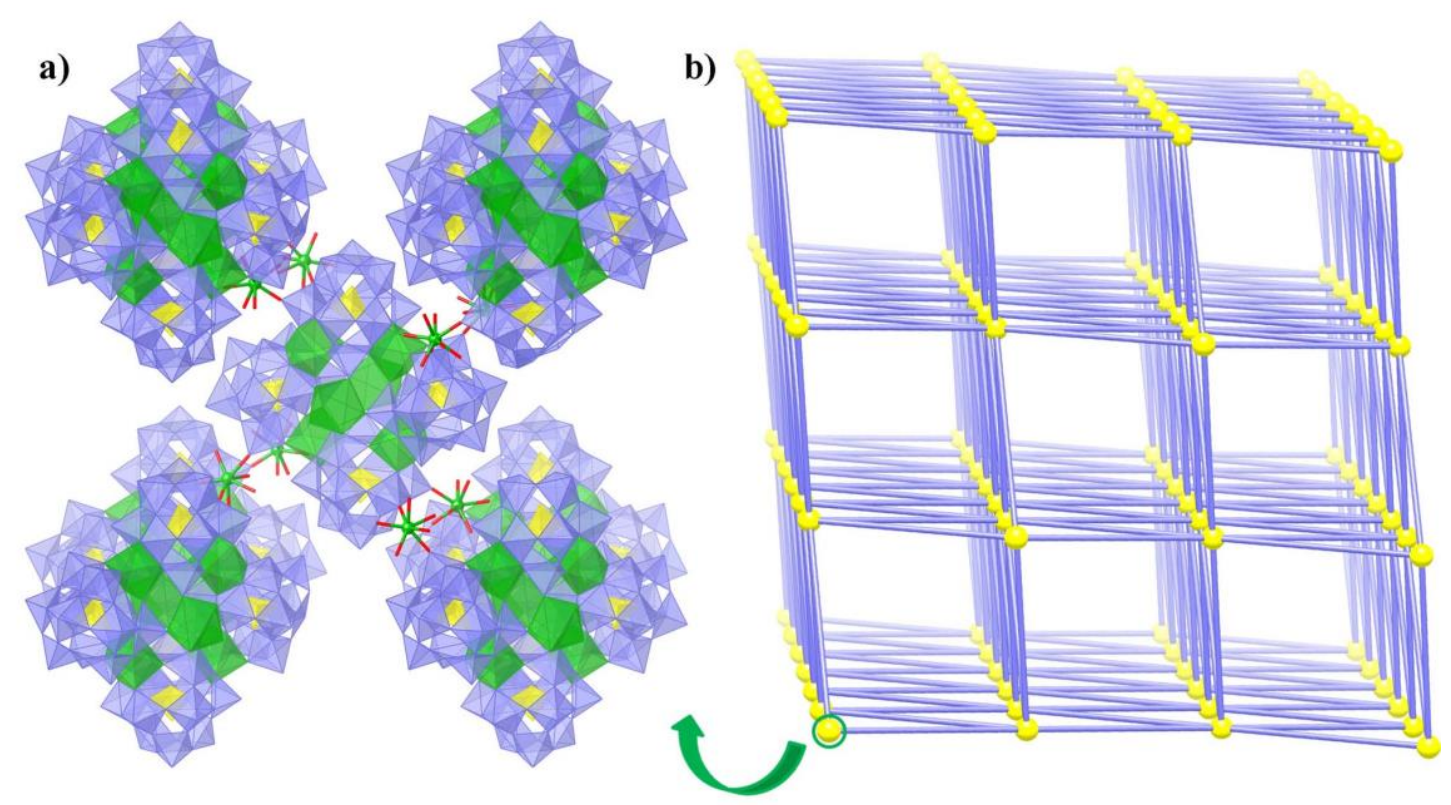

Figure S7 View of the topology of the 3D framework for 1-Gd. Each $\left\{\left[\operatorname{Ln}_{3}\left(\mathrm{H}_{2} \mathrm{O}\right)_{3}\left(\alpha-\mathrm{SiW}_{11} \mathrm{O}_{39}\right)_{2}\right]_{2}\right\}^{14-}$ cluster function as eight-connected node.
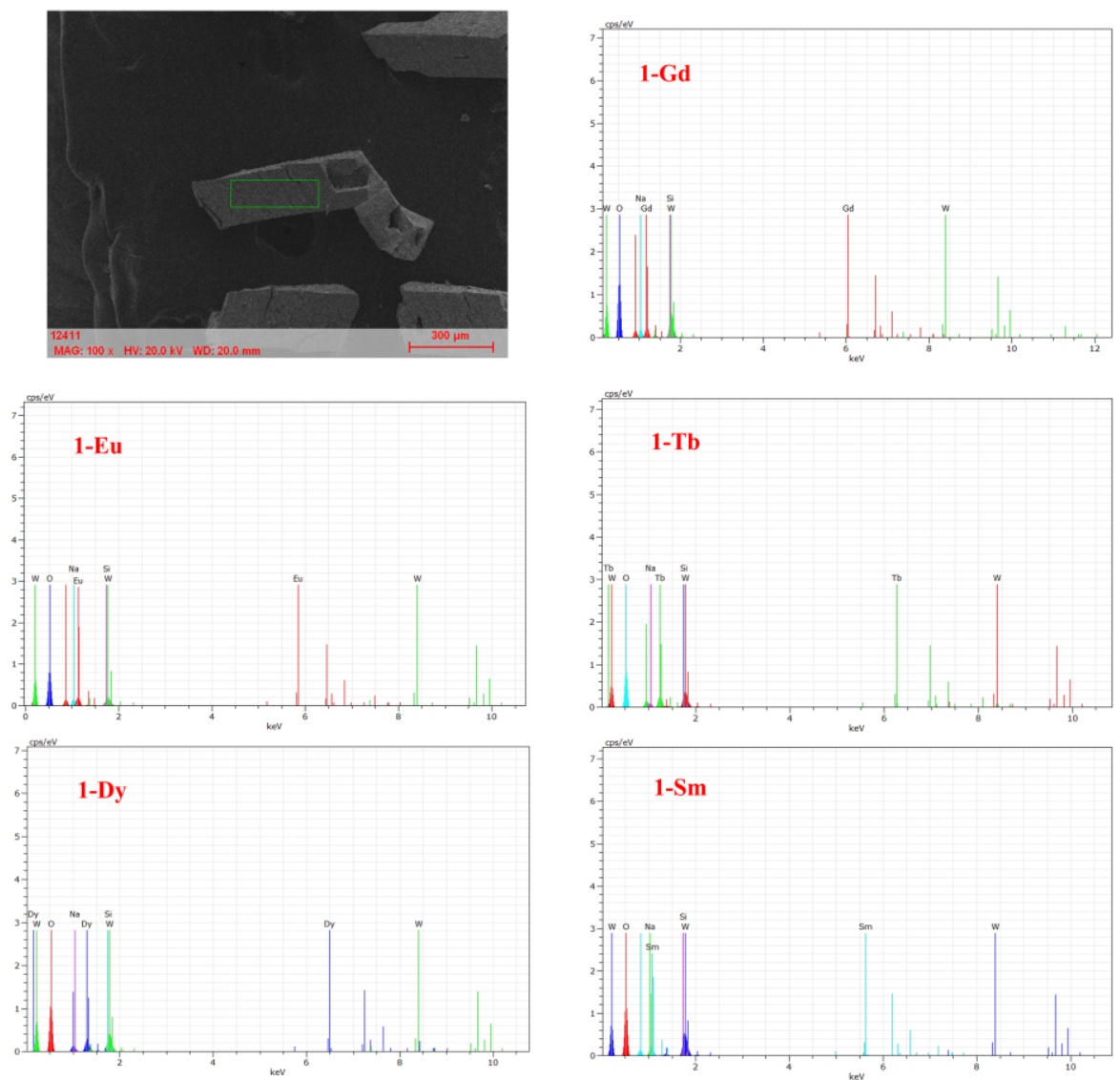

Figure S8 SEM and EDS images of 1-Ln 


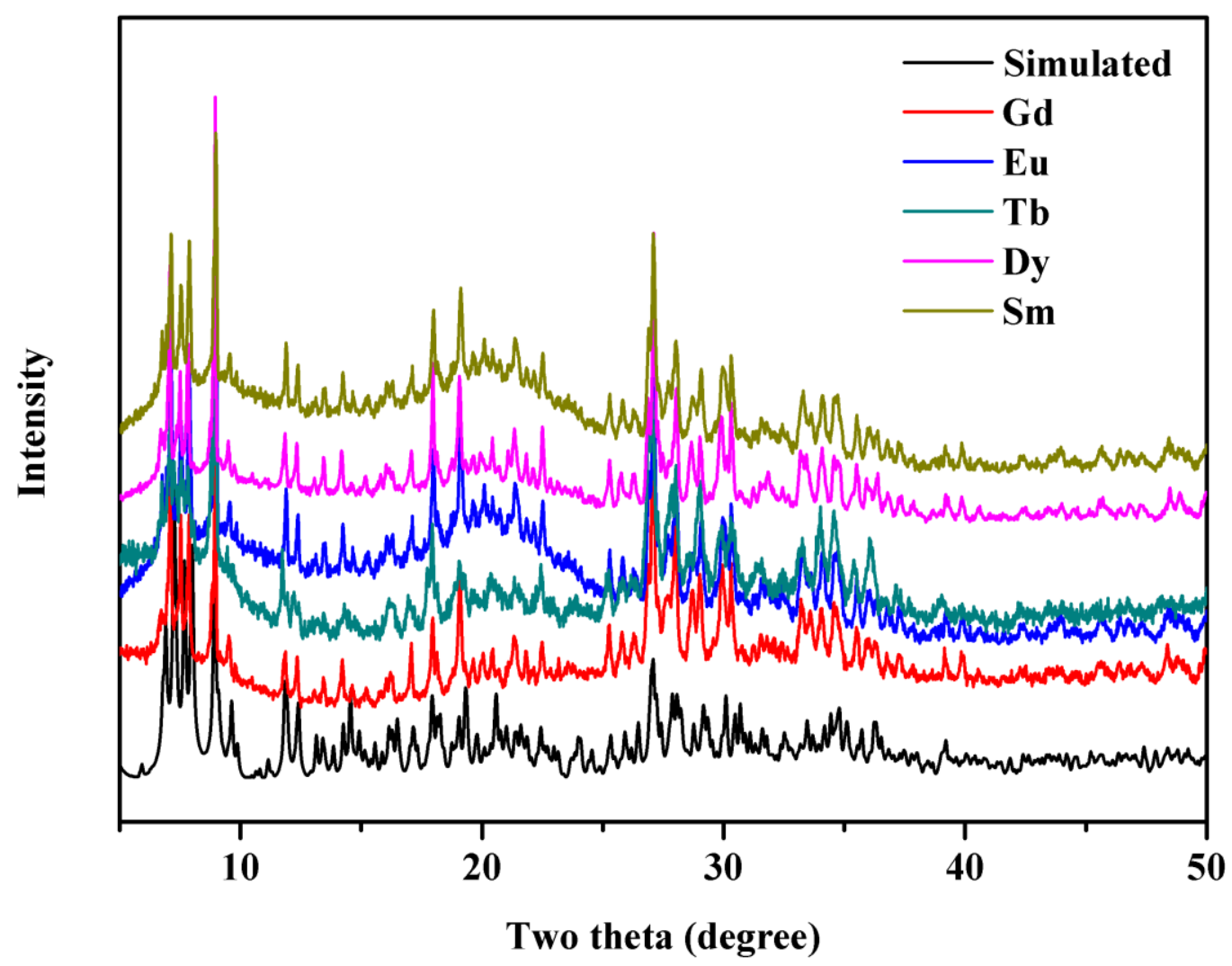

Figure S9 The simulated and experimental PXRD patterns of 1-Ln.

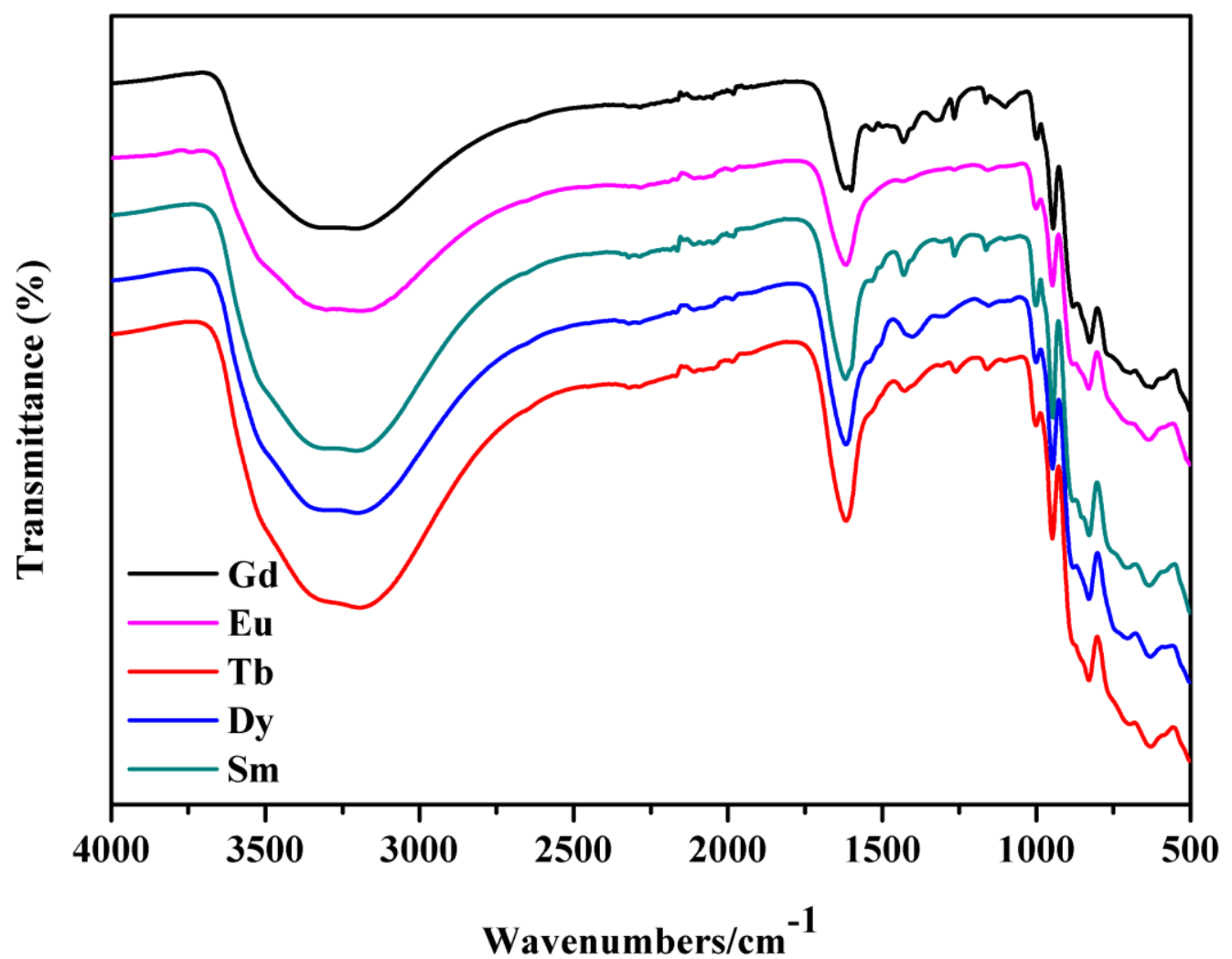

Figure S10 IR spectra of 1-Ln. 
In the IR spectra, the strong and wide broad bands in $3338.5-3182.6 \mathrm{~cm}^{-1}$ can be attributed to the stretching vibrations of $-\mathrm{OH}$ of the coordination water, the sharp broad band in $1617.9 \mathrm{~cm}^{-1}$ stems from the bending vibration of $-\mathrm{OH}$ of the coordination water, the bands at 942,835 and $704 \mathrm{~cm}^{-1}$ are attributed to the asymmetrical stretching vibrations of terminal $\mathrm{W}-\mathrm{O}_{\mathrm{t}}$, corner-sharing $\mathrm{W}-\mathrm{O}_{\mathrm{b}}$ and edge-sharing $\mathrm{W}-\mathrm{O}_{\mathrm{c}}$ bands, respectively. $\left(\mathrm{O}_{\mathrm{t}}\right.$ : terminal $\mathrm{O}$ atom; $\mathrm{O}_{\mathrm{b}}: \mu_{2}-\mathrm{O}$ atom; $\mathrm{O}_{\mathrm{c}}$ : $\mu_{4}-\mathrm{O}$ atom).

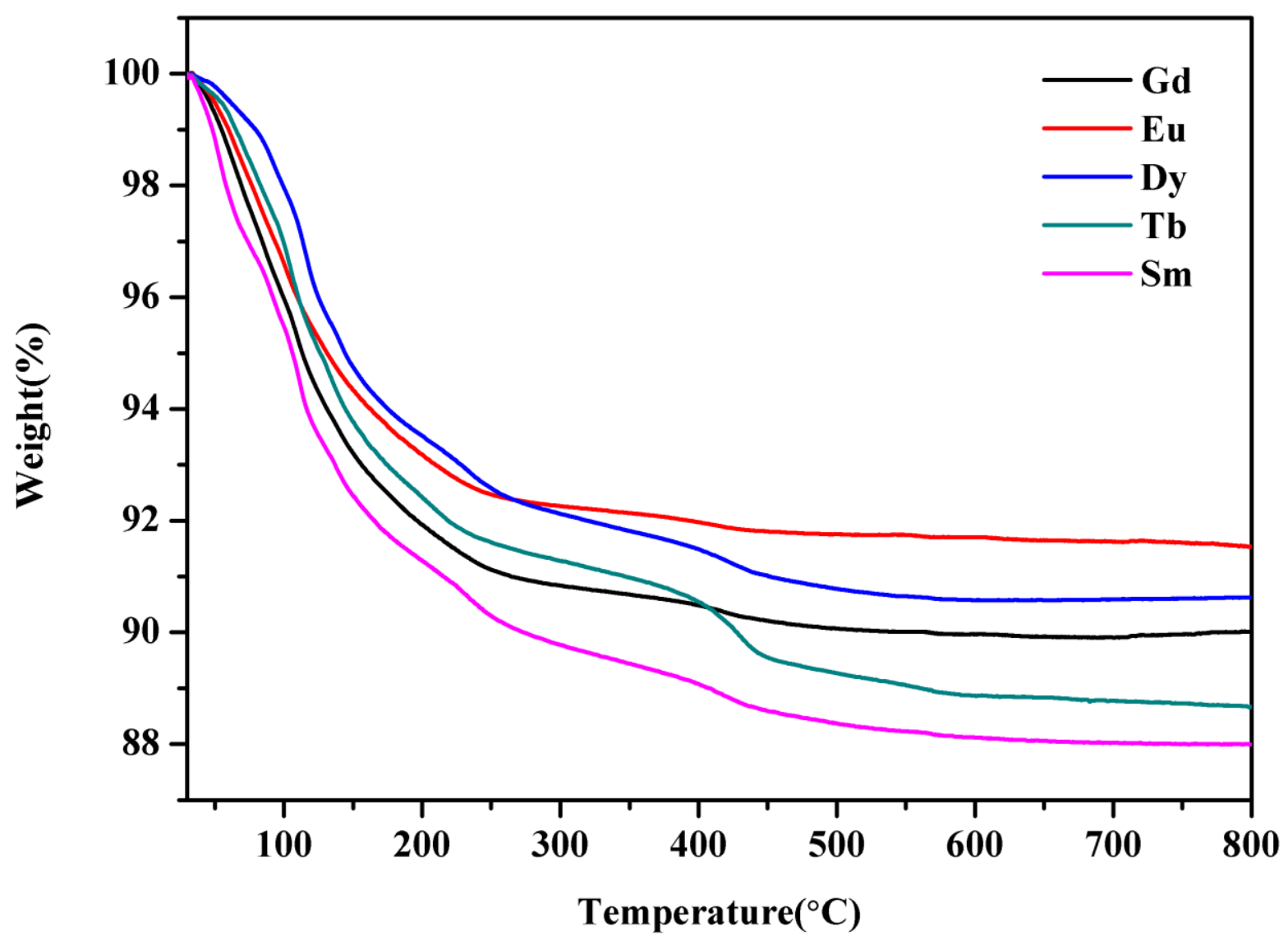

Figure S11 TGA curves of 1-Ln. 

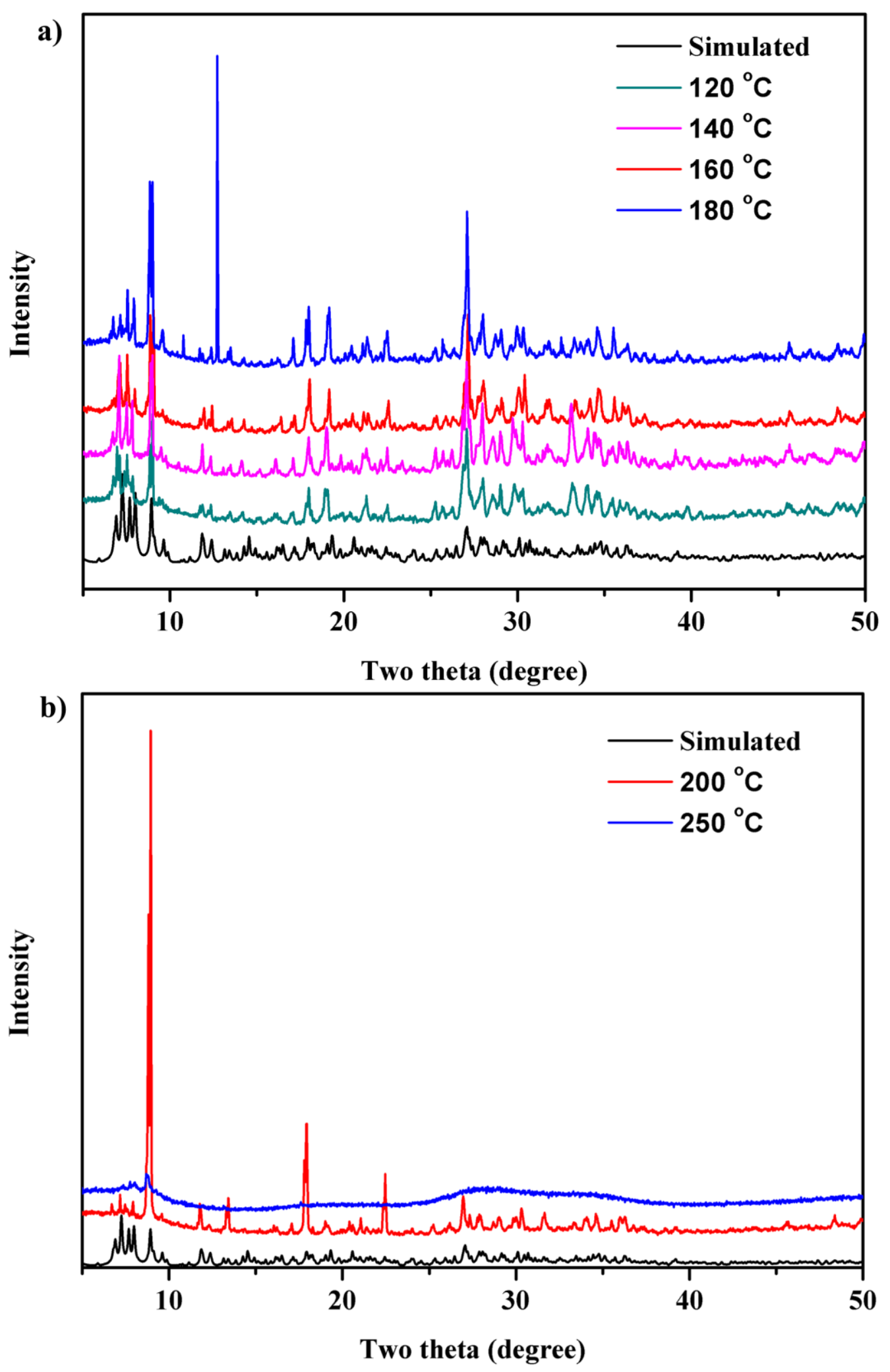

Figure S12 The simulated and variable-temperature experimental PXRD patterns of 1-Gd. 


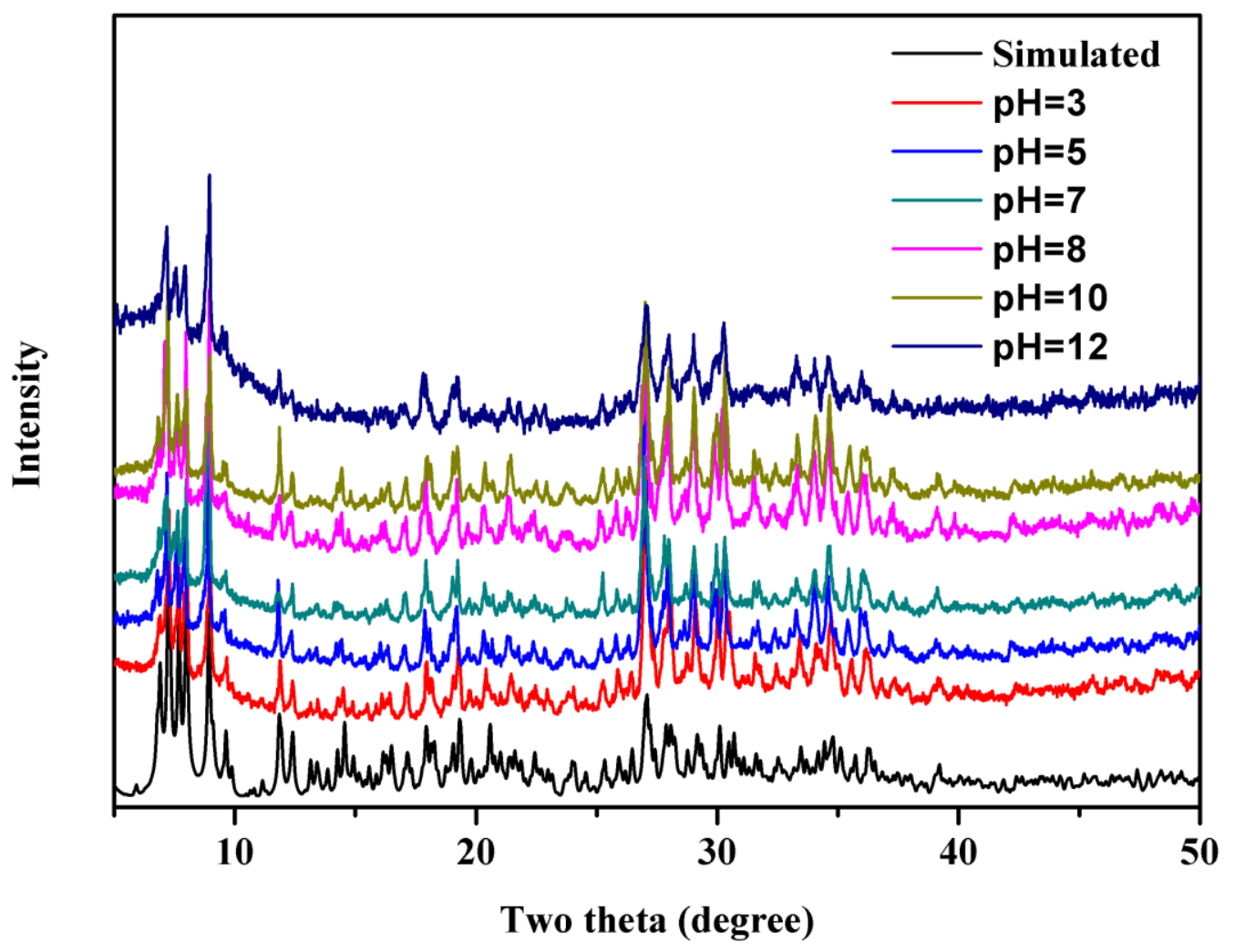

Figure S13 PXRD patterns of 1-Gd after being soaked in different concentrated $\mathrm{HCl}$ and $\mathrm{NaOH}$ aqueous for 24 hours.

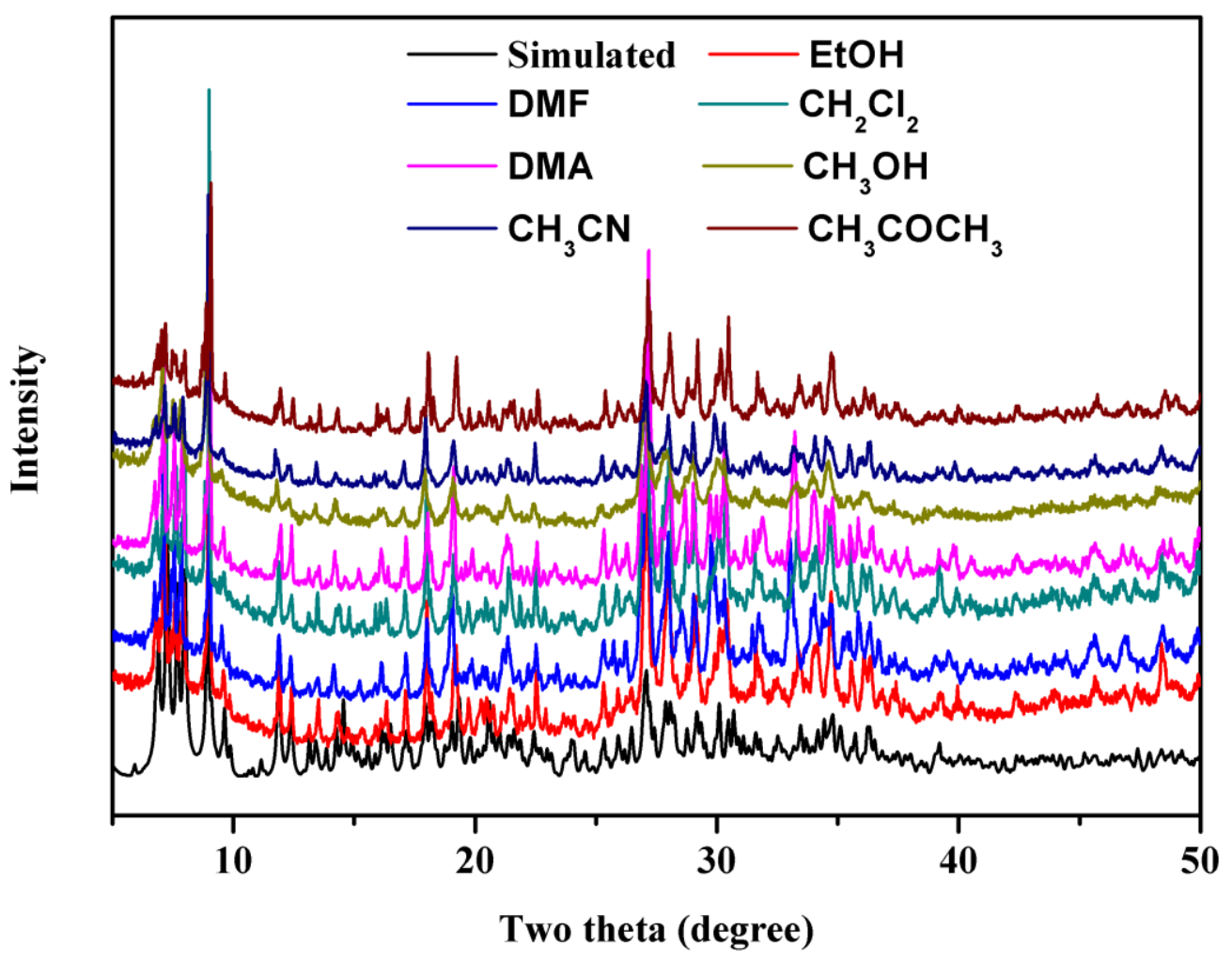

Figure S14 PXRD patterns of 1-Gd after being soaked in different organic solvent for 24 hours.

"EtOH = ethanol, DMF $=\mathrm{N}, \mathrm{N}$-dimethylformamide, $\mathrm{CH}_{2} \mathrm{Cl}_{2}=$ dichloromethane, DMA= N, N'-dimethylacetamide, $\mathrm{CH}_{3} \mathrm{OH}=$ methanol, $\mathrm{CH}_{3} \mathrm{CN}=$ acetonitrile, $\mathrm{CH}_{3} \mathrm{COCH}_{3}=$ acetone" 

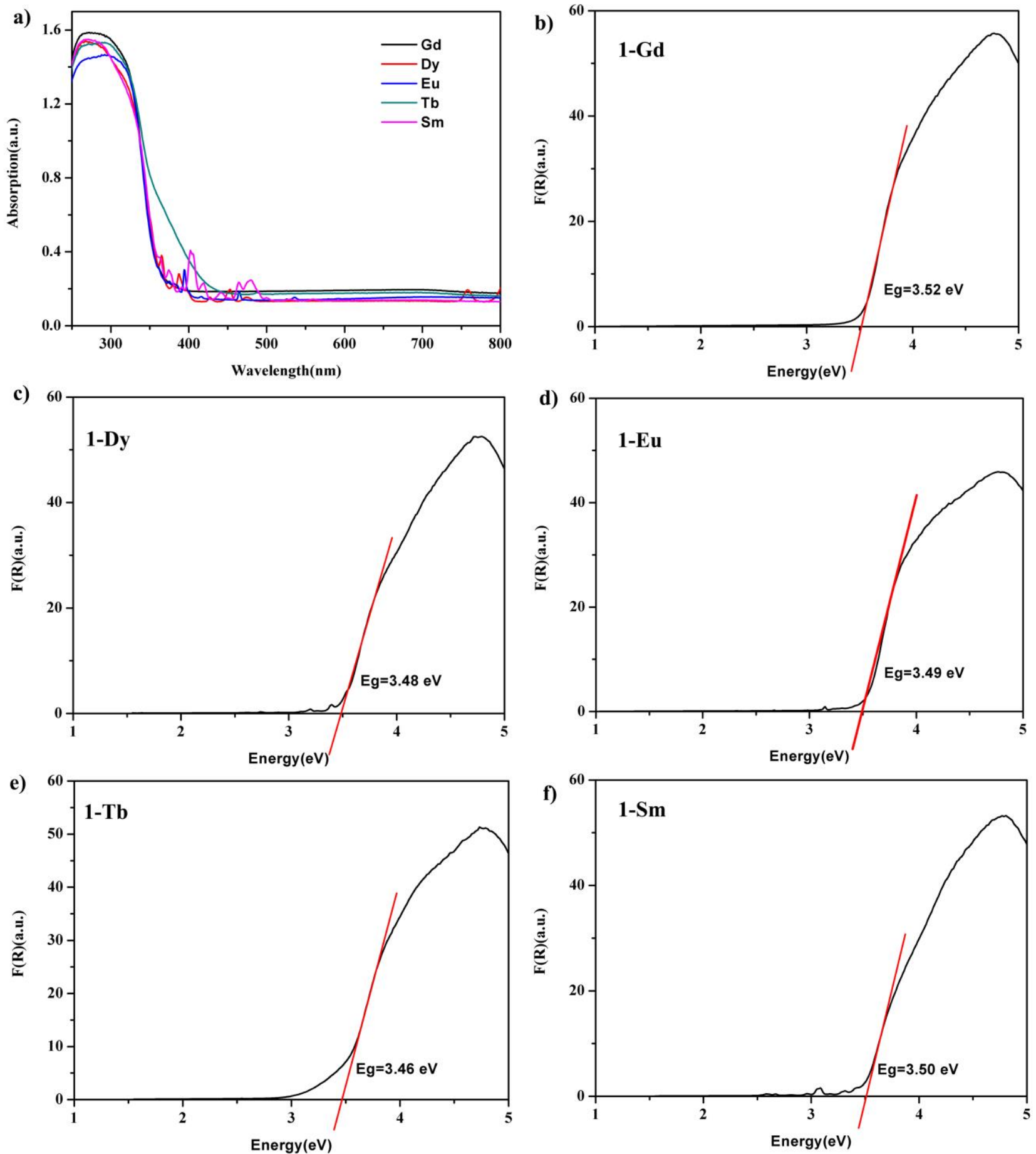

Figure S15 (a) Plots of UV-vis absorption spectra of 1-Ln. (b)-(f) Plots of Kubelka-Munk function of 1-Ln band gaps. 


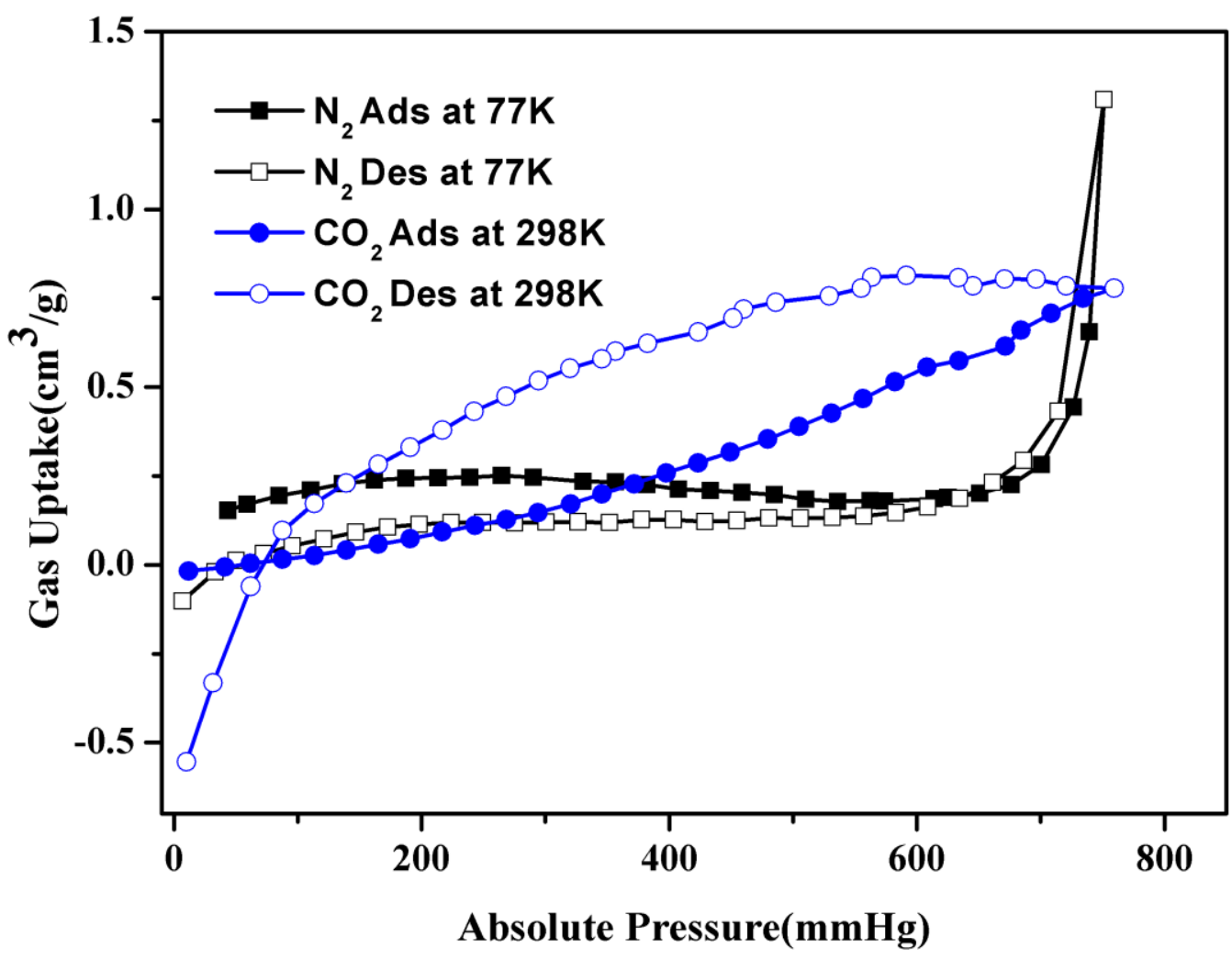

Figure $\mathbf{S 1 6} \mathrm{N}_{2}$ and $\mathrm{CO}_{2}$ sorption isotherms of 1-Gd at 77 and $298 \mathrm{~K}$, respectively.

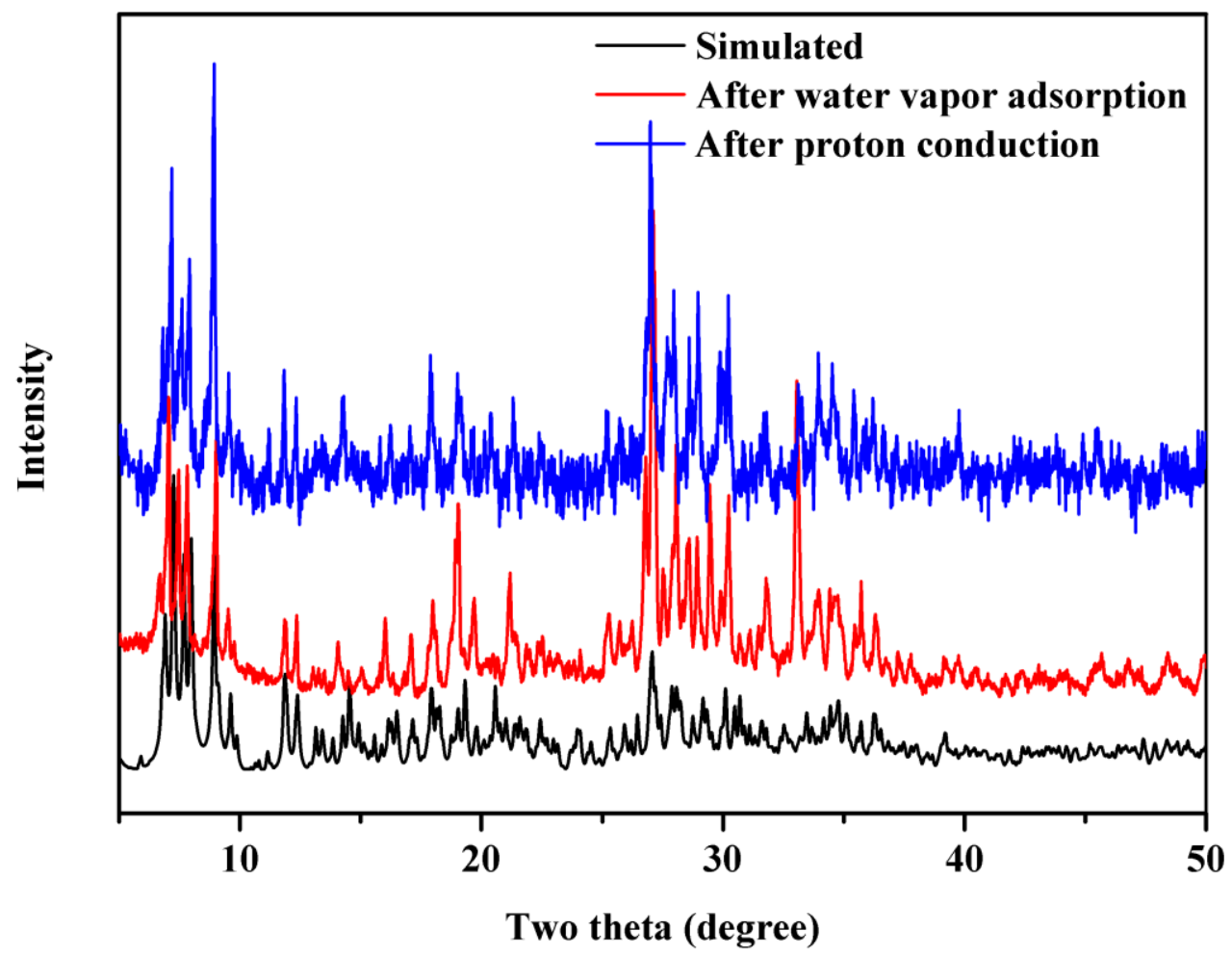

Figure S17 PXRD patters after water vapor adsorption and proton conduction for 1-Gd. 


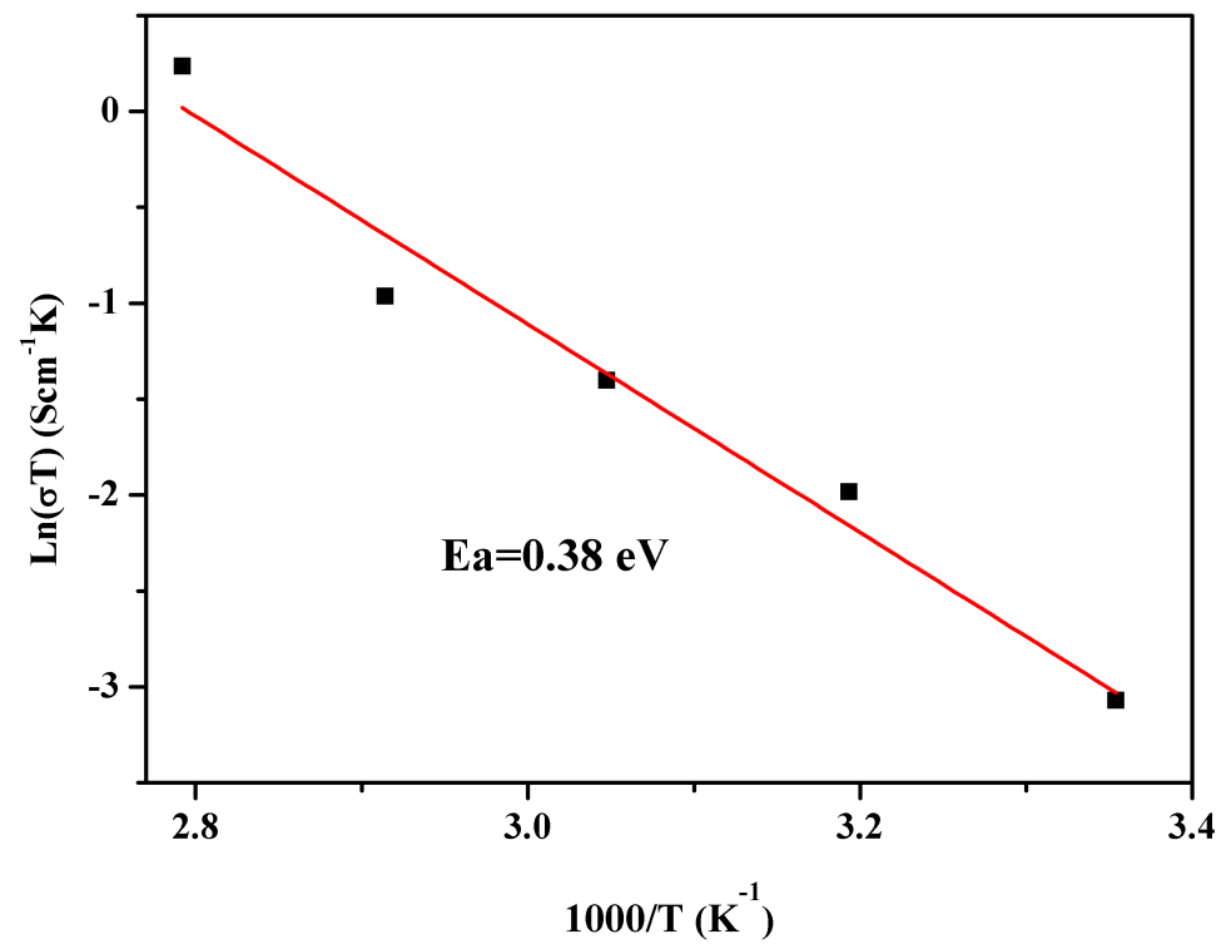

Figure S18 Arrhenius plot of the conductivity of 1-Gd.
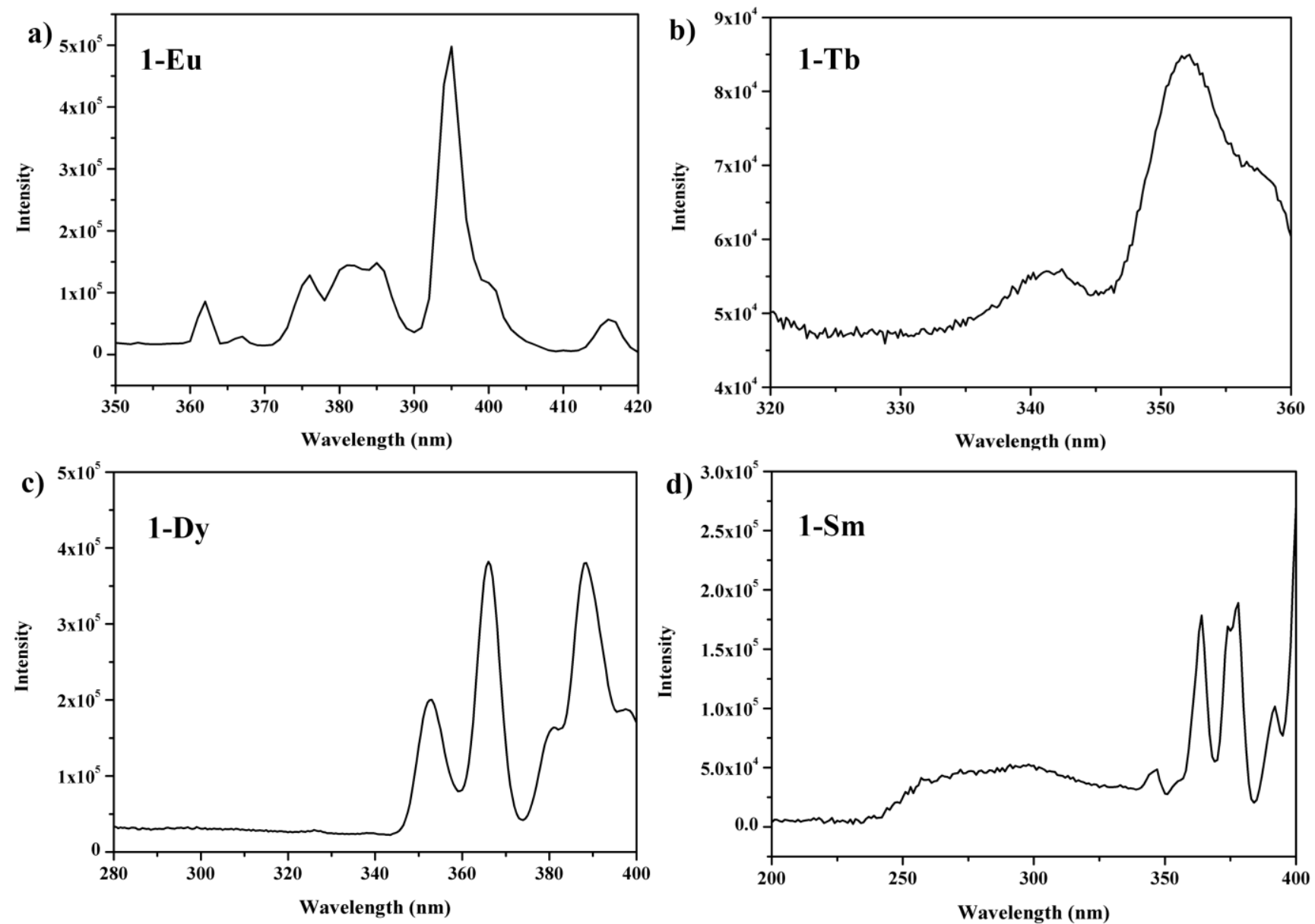

Figure S19 The excitation spectra of 1-Ln: a) 1-Eu, b) 1-Tb, c) 1-Dy and d) 1-Sm. 

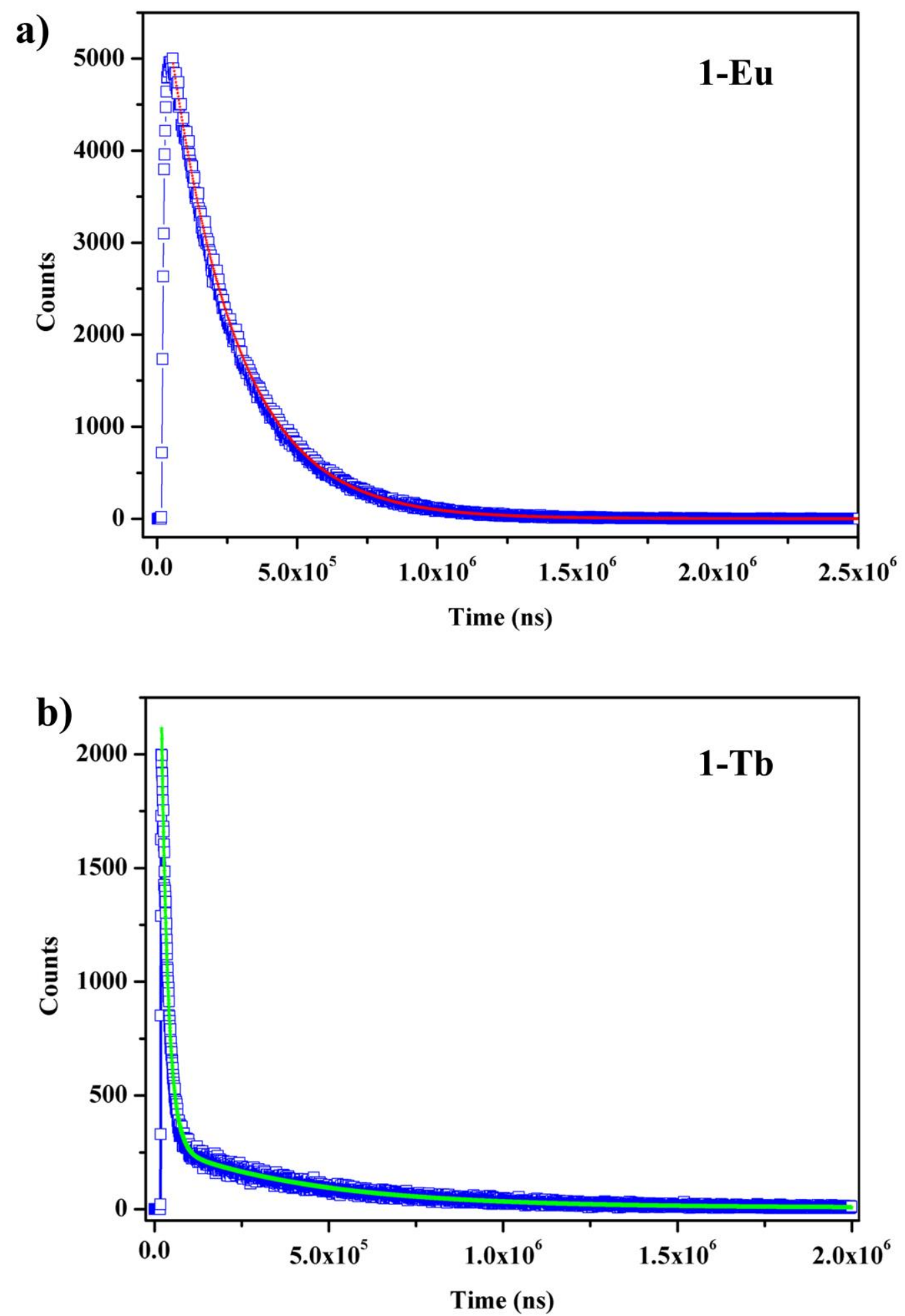

Figure S20 The luminescence decay curves of (a) 1-Eu and (b) 1-Tb. 

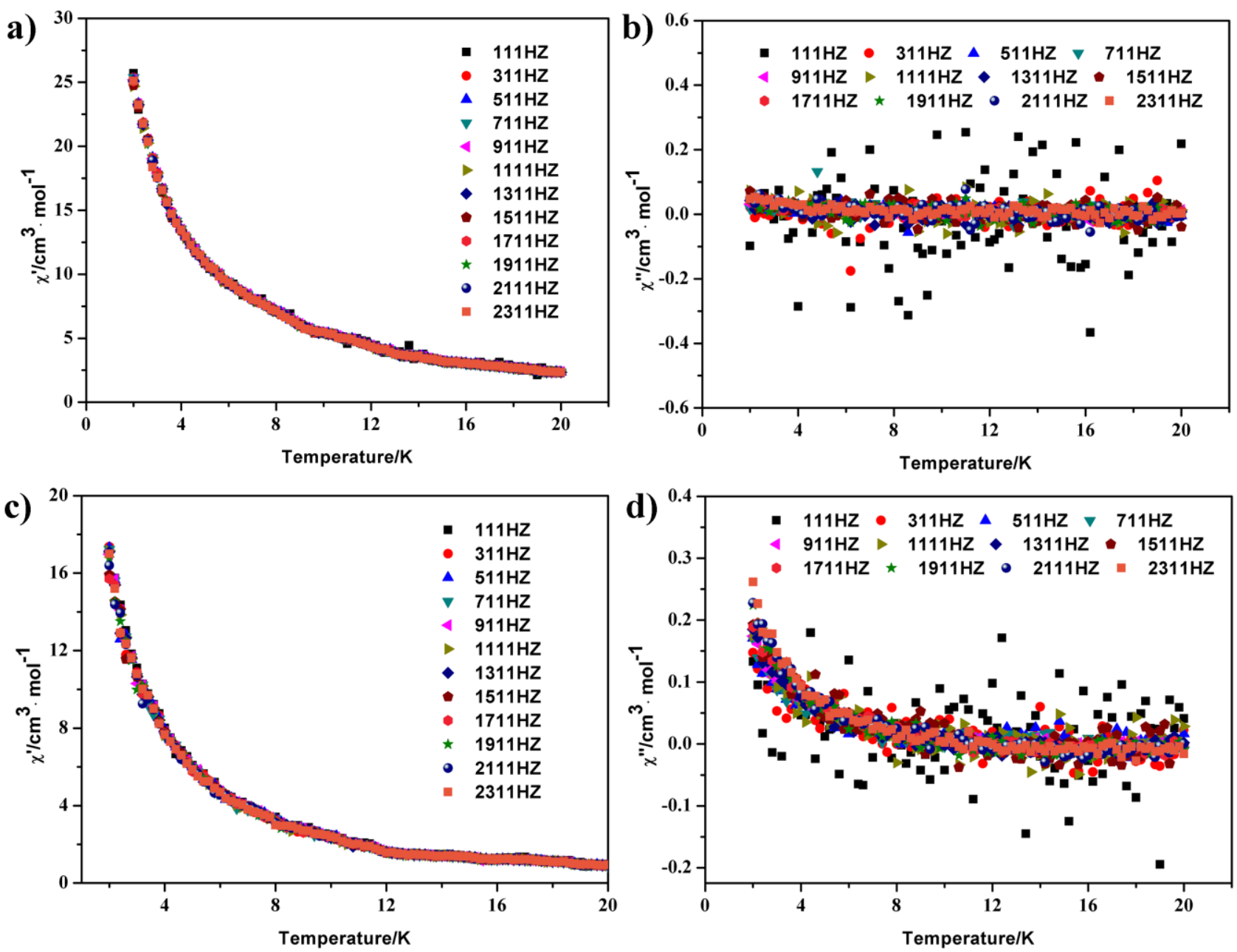

Figure S21 Frequency-dependent behavior of $\chi_{m}^{\prime}$ and $\chi^{\prime \prime}$ for 1-Tb (a and b) and 1-Dy (c and d) in zero static field at 2 $20 \mathrm{~K}$. 


\section{Section 4: References}

(1) Tézé, A.; Hervé, G.; Finke, R. G.; Lyon, D. K. Inorg. Synth. 1990, 27, 85-135.

(2) Sheldrick, G. M. A Short History of SHELX. Acta Crystallogr., Sect. A: Found. Crystallogr. 2008, 64, 112122.

(3) (a) Spek, A. L. Single-crystal Structure Validation with the Program PLATON. J. Acta Crystallogr. 2003, 36, 7-13. (b) Sluis, P. van der and Spek, A. L. BYPASS: an Effective Method for the Refinement of Crystal Structures Containing Disordered Solvent Regions. Acta Crystallogr. Sect. A. 1990, 46, 194-201.

(4) Liu, J. C.; Han, Q.; Chen, L. J.; Zhao, J. W.; Streb, C.; Song, Y. F. Aggregation of Giant Cerium-Bismuth Tungstate Clusters into a 3D Porous Framework with High Proton Conductivity. Angew. Chem. Int. Ed. 2018, $57,8416-8420$.

(5) Jiao, Y. Q.; Zang, H. Y.; Wang, X. L.; Zhou, E. L.; Song, B. Q.; Wang, C. G.; Shao, K. Z.; Su, Z. M. SelfAssembled Arrays of Polyoxometalate-Based Metal-Organic Nanotubes for Proton Conduction and Magnetism. Chem. Commun. 2015, 51, 11313-11316.

(6) Li, J.; Cao, X. L.; Wang, Y. Y.; Zhang, S. R.; Du, D. Y.; Qin, J. S.; Li, S. L.; Su, Z. M.; Lan, Y. Q. The Enhancement on Proton Conductivity of Stable Polyoxometalate-Based Coordination Polymers by the Synergistic Effect of MultiProton Units. Chem. Eur. J. 2016, 22, 9299-9304.

(7) Ma, P. T.; Wan, R.; Wang, Y. Y.; Hu, F.; Zhang, D. D.; Niu, J. Y.; Wang, J. P. Coordination-Driven Self-Assembly of a 2D Graphite-Like Framework Constructed from High-Nuclear Ce ${ }_{10}$ Cluster Encapsulated Polyoxotungstate. Inorg. Chem. 2016, 55, 918-924.

(8) Zhou, E. L.; Qin, C.; Huang, P.; Wang, X. L.; Chen, W. C.; Shao, K. Z.; Su, Z. M. A Stable PolyoxometalatePillared Metal-Organic Framework for Proton-Conducting and Colorimetric Biosensing. Chem. Eur. J. 2015, 21, 11894-11898. 
(9) Wei, M.-L.; Wang, Y.-X. and Wang, X.-J. Two Proton-conductive hybrids Based on 2-(3-Pyridyl)benzimidazole Molecules and Keggin-type Heteropolyacids. J. Solid State Chem., 2014, 209, 29-36.

(10)Wei, M. L.; Wang, X. X.; Sun, J. J. and Duan, X. Y. A 3D POM-MOF Composite Based on Ni( II ) ion and 2,2'-Bipyridyl-3,3'-dicarboxylicacid: Crystal Structure and Proton Conductivity. J. Solid State Chem., 2013, 202, 200-206.

(11)Wei, M. L.; Zhuang, P. F.; Li, H. H. and Yang, Y. H. Crystal Structures and Conductivities of Two OrganicInorganic Hybrid Complexes Based on Poly-Keggin-Anion Chains. Eur. J. Inorg. Chem. 2011, 1473-1478. 